\title{
The demise of a model? The state of collective bargaining and worker representation in Germany
}

Economic and Industrial Democracy 2017, Vol. 38(2) 193-234 (C) The Author(s) 2014 Reprints and permissions: sagepub.co.uk/journalsPermissions.nav DOI: I0.I I77/0|4383 IX|4559784 journals.sagepub.com/home/eid

@SAGE

\section{John T Addison}

University of South Carolina, USA; Durham University Business School, UK

\section{Paulino Teixeira}

University of Coimbra, Portugal

\section{André Pahnke}

Institut für Mittelstandsforschung (IfM), Bonn, Germany

\section{Lutz Bellmann}

University of Erlangen-Nuremberg and Institute for Employment Research (IAB), Germany

\begin{abstract}
This article investigates collective bargaining trends in the German private sector since 2000 . Using data from the IAB Establishment Panel and the German Establishment History Panel, it provides both cross-sectional and longitudinal evidence on these developments. It confirms that the hemorrhaging of sectoral bargaining, first observed in the 1980s and 1990s, is ongoing. Furthermore, works councils are also in decline, so that the dual system also displays erosion. For their part, any increases in collective bargaining at firm level have been minimal in recent years, while the behavior of newly-founded and closing establishments does not seem to lie at the root of a burgeoning collective bargaining free sector. Although there are few obvious signs of an organic reversal of the process, some revitalization of the bargaining system from above is implied by the labor policies of the new coalition government.
\end{abstract}

\section{Keywords}

Dual system, external erosion, Germany, sectoral/firm-level collective bargaining, works councils

\section{Corresponding author:}

John T Addison, Moore School of Business, University of South Carolina, I0I4 Greene Street, Columbia, SC 29208, USA.

Email: ecceaddi@moore.sc.edu 


\section{Introduction}

Collective bargaining coverage in Germany has been declining for some considerable time. Interestingly, one of the earliest and most influential analyses of this process of erosion was published in English by Hassel (1999). Hassel documented the falling proportion of employees covered by sectoral agreements and the weakening in works council coverage in the two decades of the last century. She also charted a tendency toward increasing decentralization within traditional collective bargaining, on top of that more obvious decentralization brought about by the growth of firm-level bargaining on the Anglo-Saxon pattern and, indeed, individual bargaining. For Hassel, both factors had systematically eroded the German system of industrial relations to the point where it threatened the regulative capacity and institutional resilience of the German model. ${ }^{1}$

Subsequent information on the falling share of sectoral agreements and declining membership density of employer associations and unions is generally supportive of continued institutional erosion (see, inter alia, Addison et al., 2007; Hassel, 2002; Silvia and Schroeder, 2007). But while debate over the changing face of German industrial relations and in particular the consequences of that altered state has certainly not abated - to the contrary it has both grown and sharpened - presentation of the facts of the case has been piecemeal and at important points has lagged the debate. This has certainly complicated understanding of the German situation for foreign observers. ${ }^{2}$

As a practical matter, data from the best source of information on the changing architecture of German industrial relations - the IAB Establishment Panel (see below) - have been published on an annual basis since 2004 (with the exception of 2006) in the Germanlanguage series WSI-Mitteilungen (see, for example, Ellguth and Kohaut, 2011, 2012, 2013). These annual updates are also summarized in such publications as European Industrial Relations Observatory On-line. But there is the question of accessibility of this material to non-German observers and real issues as to the breadth of coverage of summarized IAB statistics in the secondary sources. For both reasons, foreign observers may have found factual material on the structure of German industrial relations more fragmented than heretofore at a time of increasing controversy over the role of change.

The goal of the present article is to chart within a unified framework changes in the architecture of German industrial relations since the turn of the century, using the main, nationally representative dataset available to German researchers. We provide chapter and verse on the changing coverage of the dual system of industrial relations in Germany, both in terms of establishments and employees covered. That is, we examine the course of sectoral bargaining (i.e. area-wide, industry agreements) and the health of the works council entity, both severally and jointly. We also trace the development of firm-level agreements, and of course that of the collective bargaining free sector. Differences by broad region, employment size, and branch are also examined. In addition, we examine collective bargaining in establishments that are permanent stayers in the survey, noting differences between them and newly-born and failing establishments. Transitions between bargaining states are also examined over the period as a whole. And although our focus is at root descriptive, we also address whether one oft-cited factor behind the decline in collective bargaining - outsourcing - might be causally related to the decline in collective bargaining as a whole. Our focus therefore is upon the decline in the coverage of collective agreements, that is, upon a process of external erosion. At certain defined points, however, we 
also address empirically issues with a bearing on internal erosion of area-wide agreements as well.

\section{Institutional background: Decentralization and internal and external erosion}

Industrial relations in Germany is a dual system with two distinct pillars of interest representation. One pillar consists of industry-wide regional (or sectoral) collective agreements (Flächentarifverträge) between trade unions and the respective employers' associations, although there are also firm-level agreements (Firmentarifverträge) between unions and single employers (examples include Lufthansa and Volkswagen). The second pillar comprises works councils (Betriebsräte), legally-based bodies representative of all employees that operate at plant level. Works councils are endowed with far-reaching information, consultation, and codetermination rights, in addition to their role in implementing sectoral agreements and handling grievances. Formally, the first pillar sets wages and working conditions and is commonly described as distributive in function (i.e. bargaining over the division of the joint surplus). These industry-wide agreements are legally binding on all union members and members of the employer federations, but are generally extended to all employees of the parties to the agreement. German legislation formally prohibits establishment-level agreements between works councils and management that bypass industry-wide contracts. That is, works councils cannot conclude plant agreements (Betriebsvereinbarungen) on issues covered by collective bargaining unless expressly authorized to do so by the relevant sectoral agreement. For this reason it is conventional to describe their function as integrative (focusing on issues related to the size of the pie rather than its distribution). That said, it has long been recognized (even before the contractual innovations discussed below) that the contents of works agreements negotiated between establishments and their works councils have in practice ranged much beyond the terms fixed by the law (e.g. Müller-Jentsch, 1995: 60-61). Further, econometric research suggests that wages are higher under works councils (e.g. Addison et al., 2010; Gürtzgen, 2010). In short, the separation of distribution from production issues in the German system is inevitably partial. This is of course not to deny that the existence of a sectoral agreement may reduce the possibility of a works council engaging in rent seeking activities (see, for example, Hübler and Jirjahn, 2003), or for that matter that higher wages may be offset by higher productivity (termed 'rent-generation' by Brändle, 2013).

Although this is not the place for a primer on works councils, we might note that works councils are mandatory but not automatic in all establishments with at least five full-time employees. The decision to set up a works council resides exclusively with the employees. Once in place, the information, consultation, and participation or codetermination rights of the works council increase with establishment size. (Full details on the constitution and authority of the works council entity is contained in Addison, 2009.) Note, finally, that works councils are formally independent of unions. That said, unions have for some time played an important role in the election of works councilors - putting up lists of candidates in the nomination process - and most works councilors are in fact union members. It is therefore no accident that works councils have been described as pillars of union security. This dual system is near-universally credited with having reduced industrial conflict at establishment level and as having promoted trust and cooperation. 
The relatively centralized German system of wage bargaining is widely recognized as having displayed considerable stability until the end of the 1980s. This was largely achieved by virtue of the devolved labor powers of workplace codetermination (via works councils) that permitted accommodation to (creeping) decentralizing trends (Thelen, 1991). As a result, sectoral agreements continued to dominate in Germany long after their demise in countries such as Britain (Addison et al., 2011).

But the process of decentralization has accelerated since the early 1990s. Sectoral agreements that in the 1970s had sought to develop a qualitative bargaining policy (Qualitative Tarifpolitik) seeking to accommodate improvements in working life and worker protection against dislocations resulting from rationalization and technological change through a process of local workplace implementation shifted in the 1990s to embrace distinctly quantitative adjustments to be implemented at local level (see, in particular, Schnabel et al., 2006: 168). The latter process was led by developments in the metalworking industry, when the employers secured far-reaching flexibility in working time arrangements at firm level in return for a stepped reduction in normal weekly hours - from 40 to 37.4 hours in western Germany and to 39.3 hours in eastern Germany. ${ }^{3}$

These new local adjustments initially involved unions and employers reaching 'opening clauses' (Öffnungsklauseln), empowering the local actors to negotiate on matters normally dealt with by framework or sectoral agreements. In other words, opening clauses are regulated under section 4 of the 1949 Collective Bargaining Agreement Act (Tarifvertragsgesetz) and so offer a legal way to fall below the standards set under each regional and industry-wide collective contract. They are very heterogeneous, differing widely in content (see, for example, Heinbach and Schröpfer, 2007). Such contractual opt-out agreements initially comprised 'hardship clauses' (Härtefallklauseln) where the local actors could apply to the collective bargaining parties for relief from contractuallyagreed terms to preserve their economic viability - these clauses were first introduced in eastern Germany in the aftermath of reunification but then applied in western Germany as well - and opt-out arrangements allowing for plant-level agreements that deviated from collective agreements but which had typically to be validated by the collective bargaining parties. There were also clauses providing exemptions to small production units, allowing for individual contracts that paid less than the relevant union scales. Opening clauses on working time were dominant until the late 1990s while opening clauses on compensation are most common today (Brändle, 2013).

But the issue of company derogations (or deviations) from central agreements was already a gray area in which collectively agreed standards were undercut in a way that lacked transparency - outside of hardship clauses that contained clear procedural standards. This was partly because of the set of contractual innovations described in the next paragraph. Ambiguity led to the emergence of a system of common rules and procedures for contractual deviations, together with an attempt to gain much closer control of these processes by the leadership of unions. The most important agreement here was the socalled Pforzheim Accord reached in the metalworking industry in 2004. ${ }^{4}$ Thereafter, wildcat derogations or informal decentralization were to become less of an issue, although as Haipeter (2011a, 2011b) notes the task of exercising control over derogations in metalworking fell to the union rather than the employer after some major setbacks.

Opening clauses were an attempt by the parties to deflect pressures to decentralize collective bargaining by allowing for a modicum of differentiation while generally 
avoiding delegating decision-making rights on wages to plant level. They were to be followed by so-called 'pacts for employment and competitiveness' (betriebliche Bündnisse zur Beschäftigungs- und Wettbewerbssicherung). Although these successor agreements took their cue from opening clauses, they are often viewed as involving a more thoroughgoing form of decentralization by virtue of their concessionary bargaining nature. ${ }^{5}$ Company-level pacts are not regulated by any law directly. Initially designed to save jobs in the circumstances of a plant crisis they have become increasingly common and are today a device to increase firm competitiveness used by both struggling and prosperous firm alike (Ellguth and Kohaut, 2008; Seifert and Massa-Wirth, 2005).

Around two decades' experience with collectively agreed opening clauses has, then, changed the locus of collective bargaining in Germany. The shift in bargaining responsibilities to the company level has led to a material loss in regulatory power of the trade unions and employer associations. Collectively-agreed standards - once taken as fixed norms - have now become the objects of renegotiation at company level with varying degrees of involvement of the signatories to area-wide agreements. Unions have had to engage more directly with (the needs of) firms, while works councils have had to accommodate to management calls for local concessions rather than being able to rely on the mandatory character of sectoral regulations. Greater coordination has been required of unions to defend standards within individual sectors, at a time when the distinction between works councils and unions, once the hallmark of the dual system, has become blurred. These changes taken in conjunction with the fall in union membership (and that of employer associations) and the growth in the non-union sector (Artus, 2008), increased wage dispersion (Dustmann et al., 2009), the emergence of a low wage sector (Bosch and Weinkopf, 2008; Holst et al., 2010), and a decline in works council coverage (Kommission Mitbestimmung, 1998) together constitute the crisis in German industrial relations.

As discussed by Haipeter (2011a: 175), there are two principal interpretations of this crisis. The first is the erosion thesis first advanced by Hassel (1999), who viewed the process of decentralization as coming from below, initiated by management from the base and inevitably leading to a decline in non-market institutions. For Hassel, German wage bargaining institutions have been transformed toward a competitively-driven model of wage regulation. Hassel (2014) emphasizes segmentation, namely the emergence of an exportoriented high skill industry on the one hand and a low cost domestic services sector on the other, upon which the former depends to control labor costs. Although collaboration with labor - the hallmark of the old system - is still practiced, this cooperation and coordination applies only to an inner core of largely manufacturing firms that hire a 'mix and match' of core employees and fringe employees (often subcontracted to cheaper service suppliers). ${ }^{6}$ An increasingly dualist German economy has created an export-oriented high skill industry, depending upon a domestic environment of low cost services to control labor costs, sustained by wage subsidies for the unskilled, the lack of a minimum wage, and wage declines in the service sector - in addition to the contribution of offshoring proper.

The other main industrial relations view is Streeck's (2010) exhaustion thesis, namely a disorganized retreat of collective bargaining that is expected to generate a reinstitutionalization characterized by the replacement of statutory institutions with new institutions formed voluntarily by the market actors and typified by pacts. Since these pacts were from the outset consistent with deviations from the norms of collective bargaining they were part and parcel of the process of the internal erosion of collective bargaining norms. 
The new mode of coordination between capital and labor on this view is, then, one based on the exchange of job security for concessions on the part of labor.

Haipeter (2011a, 2011 b, 2013) offers a dissenting opinion, arguing that we are at once witnessing a process marked by both erosion and renewal, pending the resolution of which reports of the demise of the German model are premature. They are premature because they ignore the power of the system to react to the problems of erosion and disorganization at a time when the component institutions are still strong enough to selfrepair. Haipeter describes how unions have sought to use the derogation process - where firms seek to undercut standards - as a starting point to build organizational power at the workplace through the greater involvement of the rank and file in the process of renegotiation. Haipeter also notes parallel innovation on the employer side, with the setting up of 'unbound' employer associations, offering members traditional services but without requiring them to follow collective agreements. So, the idea is that unions become stronger vis-a-vis local firms seeking derogations who are induced to make compromises in the form of quid pro quos. In this situation, the strike threat is said to have increased the attractiveness of the employer association entity that has meantime also built up its strength. The net result can be a reliance again on the benefits of industry-wide standards - a renewal of the old social partnership at industry level. But this outcome is hardly guaranteed. While research indicates some positive results in favor of union revitalization, there is no suggestion that the revitalization strategy has been realized across the board (see also Silvia, 2013: 166-176). A further issue is the health of the works council institution since works council strength is a prerequisite of a proactive strategy. If works councils are in decline any such external erosion threatens revitalization and the reversal of internal erosion - organic revitalization as it were. Absent adequate employee representation at the workplace and company levels, decentralization of collective bargaining is likely to strengthen unilateral decision-making by management.

Before tracing the implications of the above contextualization for our own analysis, it is instructive to briefly address the work of economists in this area, ${ }^{7}$ not least since a much publicized recent article argues that the changes in collective bargaining have proven both central and transformative to economic performance. Dustmann et al. (2014) attribute the dramatic changes in German employment and competitiveness to industrial relations developments, and in the process downplay the role of labor market and other reforms. For these authors the prime mover is the 'inherent flexibility' of the German system of industrial relations. In particular, wage restraint and a dramatic decrease in real wages at the lower end of the wage distribution are attributed to the twin influences of the declining coverage of collective agreements on the one hand and contractual innovation on the other, specifically 'the increase in opening clauses that strengthened the role of firm-based works councils in wage determination relative to trade unions' (Dustmann et al., 2014: 181). It is argued therefore that the specific governance structure of the German system of industrial relations has allowed for an unprecedented increase in wage flexibility through decentralization. Empirical evidence in support of the proposition is based on an examination of the counterfactual changes in wages that would have occurred had collective bargaining coverage rates remained unchanged over the sample period examined (1995-2008) and on a description of (rising) wage inequality at the top and the bottom of the wage distribution in the covered sector. Interestingly, given their emphasis upon the system of industrial relations, the authors do not examine wage changes or wage distributions attendant upon a change in union status, 
nor do they directly examine the effects of opening clauses (or pacts) on wages or of the interplay between works councils and trade unions. ${ }^{8}$

Indeed, economic studies of decentralization in its two main guises are decidedly sparse. ${ }^{9}$ However, some results pertinent to the analysis of Dustmann et al. (2014) are as follows. First, there is the surprising finding that opening clauses do not seem to influence a firm's decision to exit from a sectoral agreement (Ellguth and Kohaut, 2010). Second, as regards wages, higher wages induced by the presence of opening clauses (interpreted as a potential price for flexibility or insurance policy) seem to be followed by lower wages in the event of their application (Garloff and Gürtzgen, 2012). But works councils seem to blunt both of these effects and they are independently associated with higher wages as well (Ellguth et al., 2014), so that decentralizing bargaining structures cannot simply be equated with relinquishing bargaining power. That said, one recent study suggests that flexibility provisions may not drive works council behavior toward rent seeking in circumstances where there is a sectoral agreement (Brändle, 2013). Third, there is no indication that opening clauses positively influence export activity (Heinbach and Schröpfer, 2008), or in their application foster employment growth (Brändle and Heinbach, 2013). Fourth, pacts have ambiguous consequences for training investments (Bellmann and Gerner, 2012a), the economic situation of the firm (Hübler, 2006), investments in physical capital (Bellmann et al., 2014), and, with the exception of the most recent study, for employment as well (Bellmann and Gerner, 2012b; Bellmann et al., 2008; Hübler, 2005a, 2005b). Finally, there is little evidence that leaving a collective agreement has a dramatic effect on wages (Addison et al., 2014). In sum, the labor economics literature is something of a mixed bag in its evaluation of the decentralization process.

Taking this backdrop into account, it is clear that there are several facets to the erosion thesis. For its part, the issue of contractual innovation (opening clauses and pacts) has to do with the internal erosion of sectoral agreements. This question is best examined using information on actual agreements. (For detailed studies of the bargaining system and the process of internal erosion, see Bispinck and Schulten, 2010; Doellgast and Greer, 2007; Haipeter and Lehndorff, 2009; Massa-Wirth and Niechoj, 2004.) The main dataset available to researchers does not permit identification of actual agreements and as we shall see the more general material it offers is available for a very short time period. Partly for this reason, internal erosion cannot be the preoccupation of the present inquiry. Rather, our focus is upon the coverage of collective bargaining institutions and in particular the declining proportion of production units/ employees whose wages are regulated by area-wide collective wage agreements. In addressing shrinking sectoral collective bargaining coverage, then, we are examining a process of external erosion of the area-wide collective agreement. This may of course be a function of bargaining level since a reduction in sectoral bargaining can arise from a growth in firm-level bargaining. Suffice it to say here, that the latter has been thoroughly dominated by a growth in bargaining between the firm and the worker - so-called individual bargaining - and both developments will be addressed (though not reverse feedback effects associated with any chilling effect of - flexible - sectoral agreements on firm-level bargaining). Furthermore, the decline in bargaining has not been uniform and we will need to identify external erosion by region, firm size, and industry. So as to provide a more integrated perspective on collective bargaining developments, including the role of compositional factors, we have also to examine the different samples of permanent stayers, newly-formed establishments, and establishment deaths or exits. 
The health of the other tier of the German dual system of industrial relations, namely works councils, is no less central to the question of external erosion. Changes to the Works Constitution Act (Betriebsverfassungsgesetz) in 2001 sought to expedite and facilitate their formation so as to buttress the traditional system. However, since works councils are central to the regulative capacity of the German system, their health necessarily has implications for the process of internal erosion as well since any transfer of collective bargaining functions to the plant level from above is only formally viable where works councils are in place. If plant-level codetermination is the institutional 'buckle that binds,' it follows that any substantive reduction in work councils contributes to internal erosion. Our focus on external erosion cannot then be exclusive after all. Nevertheless, in commenting upon internal erosion our approach is necessarily indirect. Apart from examining the joint presence of sectoral bargaining and works councils, we investigate the association between works council presence and contractual innovations to see if this provides protean evidence of any revitalization of the dual system from below. And, since we are speaking of revitalization, for completeness we will also need to touch upon recent political developments that offer the prospect of revitalization from above.

\section{Coverage by collective agreement and works councils: Issues and data}

The data sources used in this inquiry refer to establishments rather than to firms. The enabling survey of our principal dataset (see below) does indicate whether the establishment is a single-plant firm, but establishments belonging to multi-plant firms (i.e. all other cases) cannot be linked as component parts of the wider entity. Because we cannot speak of firms in these cases, the establishment is necessarily our unit of analysis.

Our main indicator of collective bargaining and worker representation in works councils is based on an establishment panel rather than longitudinal information on individual workers. Collective bargaining/works council coverage is measured (a) by the share of all establishments with collective agreements/works councils, and (b) by the share of total employment accounted for by these entities. We then track these changes in coverage over time. First, we use 12 cross-sections of data for the period 2000-2011 to chart yearly coverage rates. We do so for all establishments, for those establishments that remain in the panel every year (termed 'permanent stayers'), for those establishments that appear in one year but are absent in the previous year ('births'), and for plants present in one year but absent in the next or some point thereafter ('deaths'). Next, we exploit the longitudinal component to our data by examining annual transitions into and out of distinct collective bargaining/worker representation regimes - as well as the coverage rates for establishments that did not change their bargaining or worker representation status.

We disaggregate the data described below by broad region since major differences in sectoral and plant bargaining characterize eastern and western Germany from the outset of our sample period. As noted above, we also disaggregate by establishment size and sector. Note, finally, that the start of our sample period is dictated in part by substantive changes in industrial classification introduced between 1999 and 2000. We begin with the year 2000 in part to avoid having to deal (twice) with matching problems raised by such material changes in industry definition. 
Our principal dataset is the Institute for Employment Research or IAB (Institut für Arbeitsmarkt- und Berufsforschung) Establishment Panel (Betriebspanel) of the Federal German Employment Agency (Bundesagentur für Arbeit). The IAB Establishment Panel survey is based on a stratified random sample from the population of all establishments with at least one employee covered by social insurance (for a detailed description of the dataset, see Fischer et al., 2009). There are some 19 industries and 10 employment size classes in the 2011 survey. The Establishment Panel began in 1993 for the former West Germany and was extended in 1996 to the former GDR.

The data are collected in personal interviews with the owner or senior management of the establishment. The information collected focuses on employment-related matters and since 1995 has included information on the collective bargaining status of the establishment (i.e. its coverage or otherwise by a sectoral or firm-level agreement) and its works council status since 1993 (effectively in every year since 2000). These are our key institutional outcome indicators.

Given that our focus is upon the institutions of collective bargaining, we also adjust our coverage measure to consider a conflation of the works council and sectoral collective bargaining coverage. In this way, we examine the conjecture that there is a growing regulation gap in Germany, as would be manifested in a joint decline of plant-level codetermination and industry-wide collective bargaining. Also, although we cannot exploit the limited information in the parent survey on opening clauses and pacts so as to investigate their effect on the identified trends, we nonetheless examine for three cross-sections of the data information the incidence of works councils by type of contractual innovation. To repeat, our goal here is to detect signs of any revitalization of the dual system.

At the outset, the Establishment Panel was designed to provide a continuous analysis of the labor market in Germany and as a result it has an interesting longitudinal dimension, allowing us to follow a sizeable number of establishments in successive years over a substantial period of time. Over our sample period, 2000-2011, the share of establishments that is observed in every single year - permanent stayers - approximates $14 \%$. The remaining $86 \%$ comprise panel rotations together with establishment births and deaths. Pure panel rotations ranged from $11.8 \%$ of establishments in 2009 to $17.0 \%$ of establishments in 2001, averaging $13.4 \%$ over the 12 cross-sections.

The goal of separating out births and deaths is to determine whether the trends identified across broad cross-sections of the data also obtain for newly-founded establishments and plant closings. It is in particular regard to establishment births (and deaths), however, that the IAB Establishment Panel requires supplementation. The survey inquires of the establishment respondent whether or not the plant was founded prior to or after the year 1990. Only those respondents answering that the plant was born in or after 1990 are then asked to provide the exact year of birth. As a result, exclusive reliance on panel data involves a non-negligible possibility of error in coding the year of birth. Specifically, we found that for approximately $8 \%$ of all establishments over the sample period it was not possible to establish with precision from the panel whether the plant was founded before or after 1990. In addition, some $6 \%$ of those plants reporting that they were not born before 1990 failed to provide the same year of foundation in successive surveys.

Alternatively, newly-founded and failed establishments can be identified using the German Establishment Register (or Betriebsdatei) which contains in any given year all 
German establishments that have paid social security contributions for at least one of their employees. The first and last year in which an establishment is observed in the German Establishment Register may be used to determine the year of birth and death of an establishment, respectively. Because of an identical unique establishment identifier, information on the year of birth and death of an establishment can ultimately be linked to the IAB Establishment Panel. Indeed, in the initial draft of this article, we exploited this information on the first and last appearance of the establishment identifier to establish plant openings and closings. Unfortunately, this approach also has its limitations because of misclassification bias. For example, an ownership change can yield a change of the establishment identifier, so that a continuing establishment with a new identifier will be regarded as a newly-founded establishment. To overcome such measurement errors, Hethey-Maier and Schmieder (2010) have recently used worker flows to determine newly-born and failed establishments, based on German administrative data (namely, the German Establishment History Panel or Betriebs-Historik-Panel). The basic idea is that when clustered worker inflows fall below a certain percentage of all worker inflows (say 30\%) in the first year of an establishment identifier then the establishment can be called a new establishment and, equivalently in the case of an exiting establishment, an establishment death where clustered outflows are below $30 \%$ of employment in the year before an exit. In this way, Hethey-Maier and Schmieder provide very credible information on entries and exits of establishments, inter alia, between 1975 and 2004. So much so that the Research Data Centre of the Institute for Employment Research now offers regularly updated versions of these data. Information on establishment births and deaths currently covers the intervals 1975-2010 in the case of births and 1975-2009 for deaths. (For a detailed description of this material, see Hethey-Maier and Seth, 2010.) And using the common establishment identifier, we are able to match this dataset to our sample of the IAB Establishment Panel.

The upshot of this procedure is that it enables us to determine in any given year (a) whether the establishment is in the panel for the first time; (b) whether it is a continuing or a newly-born entity; (c) whether it is present in the panel in any of the following years; and (d) whether a firm exit from the panel is due to pure rotation or death. Aggregating across categories, we can in turn compute in any given year the share of births, deaths, and permanent stayers, inter alia. As we have indicated, any such exercise is impossible using the IAB Establishment Panel alone. And, to repeat, the goal is to determine whether the trends identified across broad cross-sections of the data also obtain for newly-founded establishments and plant closings.

Over the entire 2000-2011 period, the raw sample contains some 185,000 observations. Exclusions comprise agriculture, the extractive industries, public corporations, and all establishments with fewer than five employees (since this is the employment threshold for works council formation). After these filters were applied, missing values on collective bargaining and works council status resulted in the loss of a further 11,741 observations. The final sample was approximately 105,000 observations. All the empirical results reported below are cross-section weighted, using the inverse of the selection probability. Given the nature of the weighting process, it is generally the case that an establishment is allocated different weighting factors in any two subsequent waves. (For this reason the sample of permanent stayers though uniform throughout varies in size with the cross-section weights.) 


\section{Collective bargaining and works councils: Coverage, trends, and transitions}

\section{Cross-sectional data}

Evidence on the coverage of collective bargaining and worker representation by establishment and by employment is presented in Figure 1 for all types of firm and in Figures 2 through 4 for the distinct categories of permanent stayers, newly-founded firms, and firm deaths. We consider each in turn. (Full tabular material corresponding to the graphical information is provided in Appendix Tables A1 through A4.)

All types of establishment. Beginning with coverage by establishment, we see that at the allGerman level collective bargaining has declined (panel (a), Figure 1). But the decline is confined to sectoral bargaining. Specifically, establishment coverage of sectoral bargaining is down from $47.9 \%$ in 2000 to $32.9 \%$ in 2011 , while there is no concurrent growth in firmlevel collective bargaining (coverage actually falls modestly from $3.1 \%$ to $2.4 \%$ of establishments). The corollary is a marked growth in the proportion of uncovered establishments: plants without a collective agreement of any kind have grown from $49.0 \%$ to $64.6 \%$ of all establishments. Establishment coverage of works councils has slowly but assuredly dwindled as well (from $11.4 \%$ to $9.3 \%$ of all establishments). Thus, the downward trend in plantlevel codetermination, first detected by Hassel (1999), has continued. These (annual) trends in coverage are statistically significant for all but firm-level bargaining on this measure.

Reflecting the greater likelihood of collective bargaining in larger establishments throughout the period, when we turn to examine the coverage of collective bargaining and worker representation by employment (see panel (b) of Figure 1), the fall in sectoral bargaining emerges as somewhat more muted (down from $59.1 \%$ to $47.8 \%$ of all employees) and there is now stability in the share of firm-level agreements (at 7.2\% in both 2000 and 2011). Nevertheless, the growth in the share of workers without any collective bargaining is still pronounced (up from $33.7 \%$ in 2000 to $45.0 \%$ in 2011). Furthermore, the decline in works council coverage is still non-trivial on this employment measure (down 5.2 percentage points, namely from $47.6 \%$ in 2000 to $42.4 \%$ in 2011). All trends in coverage on this measure are statistically significant other than where noted to the contrary in Appendix Table A1.

The tabular material in Table 1 provides a simple breakdown of changes in coverage by establishment size, distinguishing between large units ( $\geq 250$ employees) and small units ( $<250$ employees) for the nation as a whole. The material makes it clear that, although the decline in sectoral bargaining and the growth in no collective bargaining are characteristic of both types of establishments, the respective percentage point rates of decline/growth in the small plant sample are roughly double those of their larger counterparts and, accordingly, the proportional changes smaller for larger establishments throughout. Similarly, works council coverage has held up better in larger establishments. Finally, although firm-level agreements are considerably more common in larger than smaller establishments, in neither case are the trends significant at conventional levels.

The analysis can be also conducted by sector. To this end, we first compare manufacturing with services. We then consider a finer, 7- and 11-sector disaggregation - covering, respectively, the 2000-2008 and 2009-2011 intervals - attendant upon the industrial reclassification of 2009. These results are provided in Tables 2 and 3. From Table 2 it can be seen 


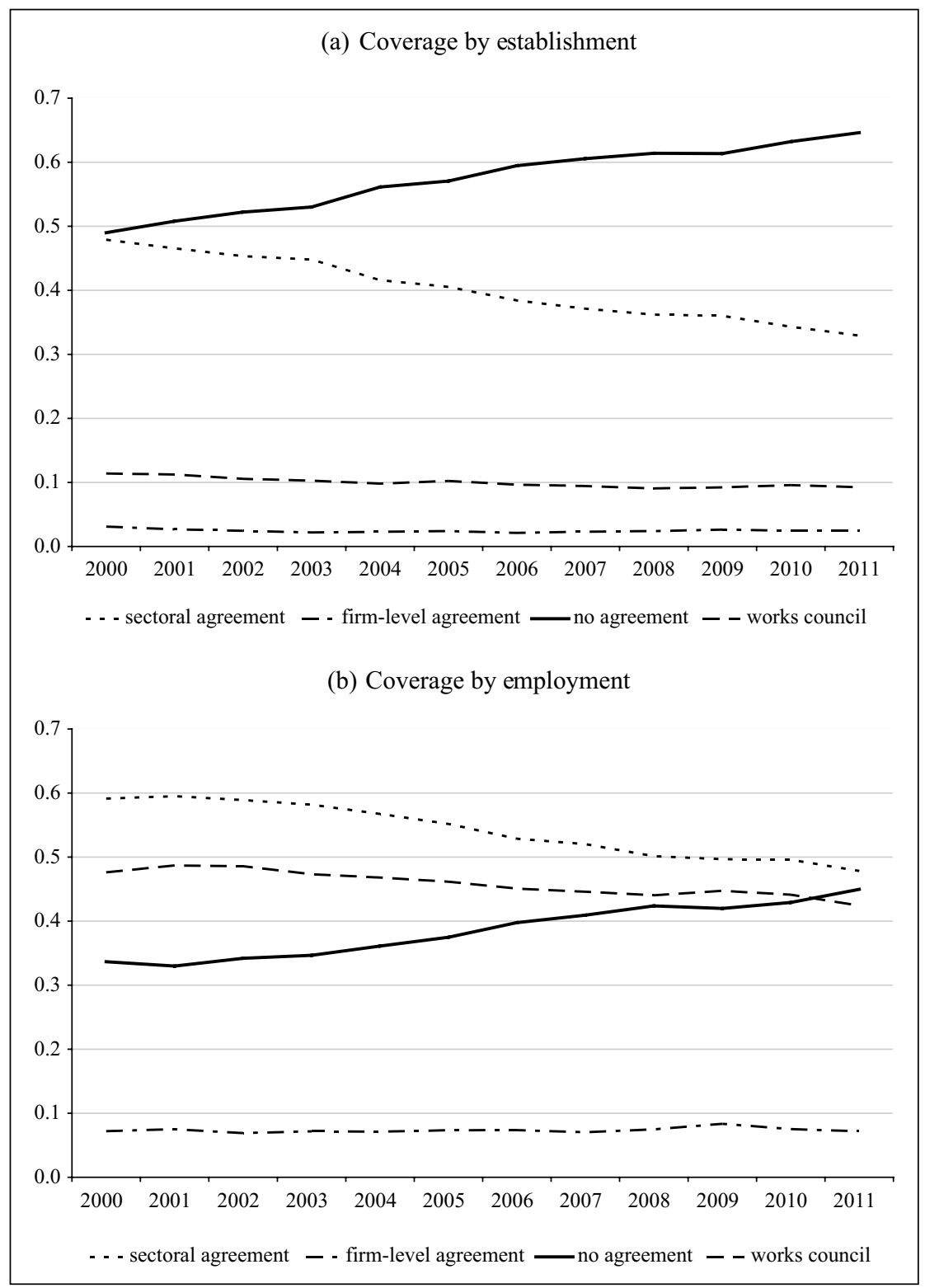

Figure I. Collective bargaining and works council coverage for Germany, 2000-20I I (establishments with at least five employees, cross-section weighted data).

that sectoral bargaining is declining in both manufacturing and construction and in services by a 10-15 percentage point margin irrespective of the selected measure (establishment or employee coverage). The frequency of firm-level agreements is sparse throughout. Absence 


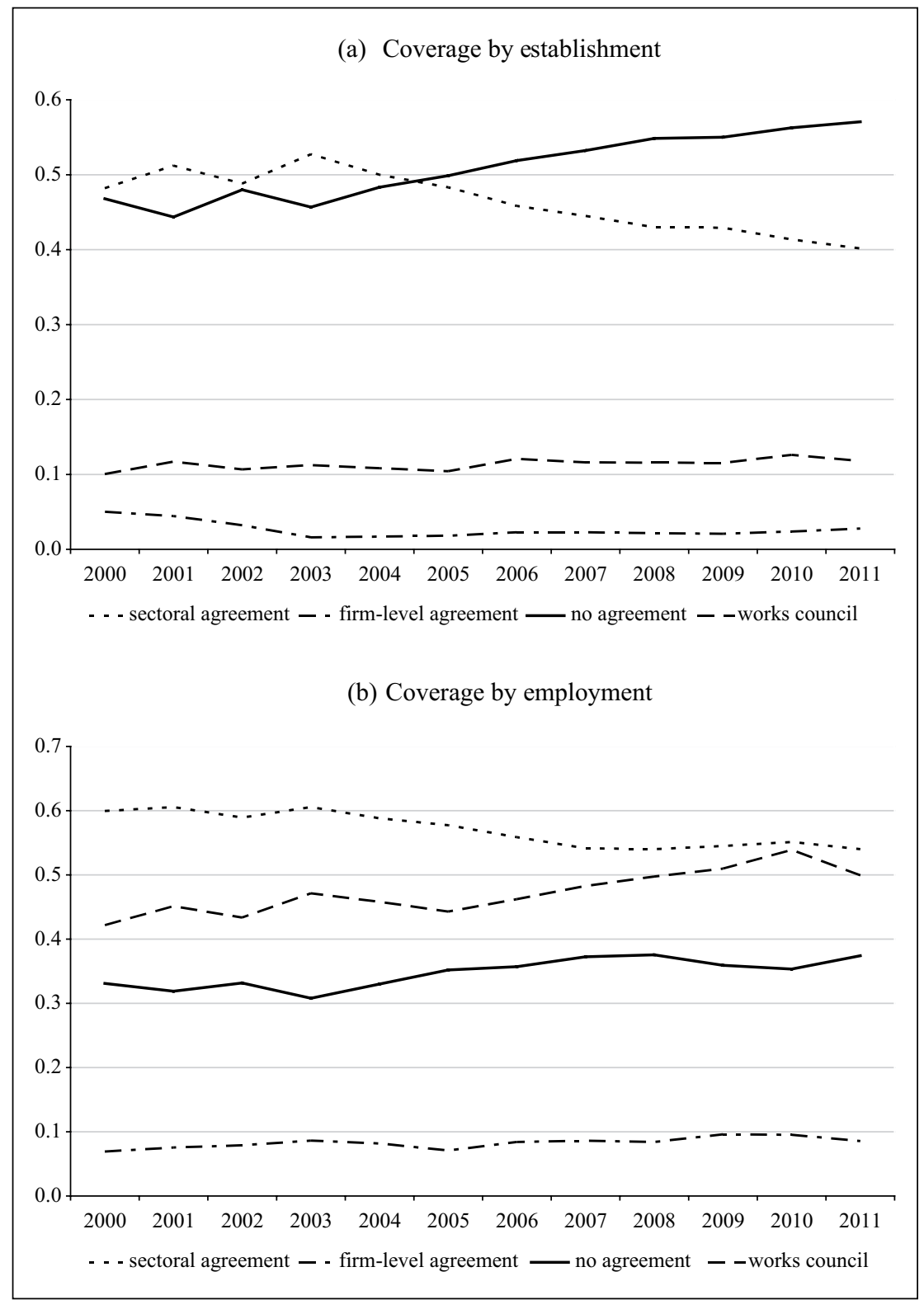

Figure 2. Collective bargaining and works council coverage for Germany, permanent stayers, 2000-20I I (establishments with at least five employees, cross-section weighted data).

of collective bargaining is more characteristic of services than in manufacturing and construction, in the range 10-15 percentage points. For their part, works councils cover roughly the same proportion of establishments in both sectors although they account for a majority 
Table I. Collective bargaining and works council coverage for Germany, 2000-20I I, by establishment size, weighted data, in percentages.

\begin{tabular}{|c|c|c|c|c|c|c|c|c|c|}
\hline \multirow[t]{3}{*}{ Year } & \multirow[t]{3}{*}{ Size } & \multicolumn{8}{|c|}{ Collective agreement status } \\
\hline & & \multicolumn{2}{|c|}{$\begin{array}{l}\text { Sectoral } \\
\text { agreement }\end{array}$} & \multicolumn{2}{|c|}{$\begin{array}{l}\text { Firm-level } \\
\text { agreement }\end{array}$} & \multicolumn{2}{|c|}{ No agreement } & \multicolumn{2}{|c|}{$\begin{array}{l}\text { Works } \\
\text { council }\end{array}$} \\
\hline & & I & II & I & II & I & II & I & II \\
\hline \multirow[t]{2}{*}{2000} & Small & 47.6 & 52.3 & 3.0 & 5.0 & 49.4 & 42.7 & 10.6 & 30.1 \\
\hline & Large & 71.7 & 76.6 & 12.0 & 12.8 & 16.4 & 10.6 & 87.6 & 92.4 \\
\hline \multirow[t]{2}{*}{2001} & Small & 46.2 & 53.0 & 2.6 & 4.5 & 51.2 & 42.4 & 10.4 & 30.7 \\
\hline & Large & 72.2 & 75.2 & 13.1 & 14.6 & 14.7 & 10.2 & 88.6 & 92.0 \\
\hline \multirow[t]{2}{*}{2002} & Small & 45.0 & $5 \mathrm{I} .1$ & 2.3 & 4.8 & 52.6 & 44.2 & 9.7 & 29.9 \\
\hline & Large & 74.0 & 77.8 & 11.1 & 12.1 & 15.0 & 10.1 & 89.7 & 93.7 \\
\hline \multirow[t]{2}{*}{2003} & Small & 44.5 & 51.4 & 2.1 & 4.4 & 53.4 & 44.2 & 9.4 & 28.9 \\
\hline & Large & 71.5 & 74.7 & 12.0 & 13.9 & 16.5 & 11.5 & 88.1 & 92.2 \\
\hline \multirow[t]{2}{*}{2004} & Small & 41.3 & 48.6 & 2.2 & 5.0 & 56.6 & 46.4 & 8.9 & 28.2 \\
\hline & Large & 70.9 & 76.8 & 12.9 & 12.4 & 16.2 & 10.9 & 88.6 & 92.7 \\
\hline \multirow[t]{2}{*}{2005} & Small & 40.2 & 47.0 & 2.3 & 5.3 & 57.5 & 47.7 & 9.4 & 28.6 \\
\hline & Large & 70.3 & 76.3 & 12.9 & 12.6 & 16.7 & II.I & 87.7 & 91.5 \\
\hline \multirow[t]{2}{*}{2006} & Small & 38.1 & 44.9 & 2.0 & 4.8 & 59.9 & 50.3 & 8.9 & 27.9 \\
\hline & Large & 67.1 & 73.3 & 13.1 & 14.0 & 19.8 & 12.7 & 83.5 & 89.2 \\
\hline \multirow[t]{2}{*}{2007} & Small & 36.8 & 43.5 & 2.2 & 5.0 & 61.0 & 51.5 & 8.6 & 26.9 \\
\hline & Large & 66.6 & 73.6 & 12.7 & 12.1 & 20.7 & 14.3 & 84.4 & 89.3 \\
\hline \multirow[t]{2}{*}{2008} & Small & 35.9 & 42.3 & 2.3 & 5.2 & 61.8 & 52.5 & 8.2 & 26.3 \\
\hline & Large & 63.8 & 70.0 & 12.3 & 13.3 & 24.0 & 16.8 & 83.3 & 88.9 \\
\hline \multirow[t]{2}{*}{2009} & Small & 35.7 & 42.7 & 2.5 & 5.4 & 61.7 & 51.9 & 8.4 & 26.8 \\
\hline & Large & 61.3 & 67.1 & 13.5 & 15.6 & 25.2 & 17.4 & 84.0 & 89.5 \\
\hline \multirow[t]{2}{*}{2010} & Small & 34.0 & 41.7 & 2.3 & 4.9 & 63.7 & 53.3 & 8.8 & 26.9 \\
\hline & Large & 64.5 & 69.9 & 13.2 & 14.2 & 22.3 & 15.8 & 83.8 & 88.9 \\
\hline \multirow[t]{2}{*}{2011} & Small & 32.6 & 39.9 & 2.3 & 5.1 & 65.0 & 55.0 & 8.4 & 25.7 \\
\hline & Large & 64.5 & 70.1 & 11.8 & 13.0 & 23.7 & 16.9 & 85.2 & 89.0 \\
\hline \multirow[t]{2}{*}{ Trend } & Small & _**** & _*** & n.s. & $+*$ & $+* * * *$ & $+* * *$ & _*** & _*** \\
\hline & Large & _*** & - **** & n.s. & n.s. & $+* * * *$ & $+* * *$ & _*** & _*** \\
\hline
\end{tabular}

Notes: I denotes the proportion of establishments and II the proportion of employees.

$* * *, * *$, and $*$ denote statistical significance at the $.01, .05$, and .10 levels, respectively.

(minority) of employees in manufacturing and construction (services). Confirming the strong stability of these patterns over time, the trend line is statistically significant at the .05 level or better in 13 of the 16 time series shown in Table 2.

The seven-sector disaggregation in Table 3 a reveals some interesting patterns as well. First of all, with the exception of one case (i.e. industrial services), the coverage of sectoral agreements is always decreasing irrespective of the selected measure. The opposite is the case for the collective bargaining free zone. Second, the presence of sectoral agreements is pervasive in banking and insurance and, to a somewhat lesser extent, in construction too. Interestingly, while works councils in banking and insurance are 
Table 2. Collective bargaining and works council coverage for Germany, 2000-20I I, by sector, weighted data, in percentages.

\begin{tabular}{|c|c|c|c|c|c|c|c|c|c|}
\hline \multirow[b]{3}{*}{ Year } & \multirow[b]{3}{*}{ Sector } & \multicolumn{8}{|c|}{ Collective agreement status } \\
\hline & & \multicolumn{2}{|c|}{$\begin{array}{l}\text { Sectoral } \\
\text { agreement }\end{array}$} & \multicolumn{2}{|c|}{$\begin{array}{l}\text { Firm-level } \\
\text { agreement }\end{array}$} & \multicolumn{2}{|c|}{ No agreement } & \multicolumn{2}{|c|}{$\begin{array}{l}\text { Works } \\
\text { council }\end{array}$} \\
\hline & & I & II & 1 & II & I & II & 1 & II \\
\hline \multirow[t]{2}{*}{2000} & Mfg \& constr. & 56.3 & 66.1 & 3.7 & 6.4 & 40.0 & 27.5 & 12.1 & 56.5 \\
\hline & services & 44.1 & 54.3 & 2.8 & 7.8 & 53.1 & 37.9 & II.I & 41.4 \\
\hline \multirow[t]{2}{*}{2001} & Mfg \& constr. & 56.2 & 66.2 & 2.1 & 7.4 & 41.7 & 26.5 & 13.2 & 59.1 \\
\hline & services & 42.3 & 55.1 & 2.9 & 7.6 & 54.7 & 37.3 & 10.4 & 41.7 \\
\hline \multirow[t]{2}{*}{2002} & Mfg \& constr. & 56.3 & 68.0 & 1.8 & 6.0 & 41.9 & 26.0 & 11.9 & 60.0 \\
\hline & services & 40.8 & 52.8 & 2.7 & 7.5 & 56.5 & 39.7 & 10.0 & 40.9 \\
\hline \multirow[t]{2}{*}{2003} & Mfg \& constr. & 55.4 & 66.8 & 1.9 & 6.3 & 42.8 & 26.9 & 11.6 & 60.0 \\
\hline & services & 40.7 & 52.6 & 2.3 & 7.7 & 57.0 & 39.7 & 9.7 & 39.1 \\
\hline \multirow[t]{2}{*}{2004} & Mfg \& constr. & 53.1 & 64.9 & 2.2 & 6.1 & 44.7 & 29.0 & 10.4 & 58.7 \\
\hline & services & 37.2 & 51.7 & 2.3 & 7.8 & 60.5 & 40.5 & 9.6 & 39.4 \\
\hline \multirow[t]{2}{*}{2005} & Mfg \& constr. & 52.3 & 62.4 & 2.1 & 7.5 & 45.6 & 30.1 & 11.4 & 59.3 \\
\hline & services & 36.0 & 50.7 & 2.6 & 7.3 & 61.4 & 42.0 & 9.8 & 38.1 \\
\hline \multirow[t]{2}{*}{2006} & Mfg \& constr. & 51.2 & 60.8 & 2.0 & 8.2 & 46.8 & 30.9 & 10.7 & 57.9 \\
\hline & services & 33.5 & 48.0 & 2.2 & 6.8 & 64.3 & 45.2 & 9.2 & 37.1 \\
\hline \multirow[t]{2}{*}{2007} & Mfg \& constr. & 48.9 & 60.0 & 2.1 & 7.8 & 49.0 & 32.2 & 10.6 & 58.7 \\
\hline & services & 32.7 & 47.2 & 2.4 & 6.6 & 65.0 & 46.2 & 9.0 & 36.1 \\
\hline \multirow[t]{2}{*}{2008} & Mfg \& constr. & 48.8 & 58.6 & 2.1 & 8.5 & 49.1 & 32.9 & 9.6 & 58.7 \\
\hline & services & 31.7 & 45.2 & 2.5 & 6.9 & 65.8 & 47.9 & 8.9 & 35.4 \\
\hline \multirow[t]{2}{*}{2009} & Mfg \& constr. & 50.9 & 58.6 & 2.7 & 8.0 & 46.4 & 33.4 & 10.6 & 56.4 \\
\hline & services & 29.9 & 44.0 & 2.6 & 8.5 & 67.5 & 47.5 & 8.6 & 37.2 \\
\hline \multirow[t]{2}{*}{2010} & Mfg \& constr. & 45.8 & 56.6 & 2.5 & 8.9 & 51.6 & 34.5 & 10.8 & 56.4 \\
\hline & services & 29.6 & 45.3 & 2.4 & 6.6 & 67.9 & 48.1 & 9.1 & 36.5 \\
\hline \multirow[t]{2}{*}{2011} & Mfg \& constr. & 44.2 & 55.0 & 2.5 & 8.2 & 53.3 & 36.8 & 10.2 & 54.8 \\
\hline & services & 28.3 & 43.4 & 2.4 & 6.5 & 69.3 & 50.1 & 8.8 & 34.5 \\
\hline \multirow[t]{2}{*}{ Trend } & Mfg \& constr. & $\_* * *$ & _**** & n.s. & $+* * *$ & $+* * *$ & $+* * *$ & _*** & _** \\
\hline & services & $\_* * *$ & $\_* * *$ & -* & n.s. & $+* * *$ & $+* * *$ & _*** & _*** \\
\hline
\end{tabular}

Notes: I denotes the proportion of establishments and II the proportion of employees. In this two-sector aggregation, construction is included in manufacturing. $* * * * *$, and $*$ denote statistical significance at the $.0 \mathrm{I}$, .05 , and .10 levels, respectively.

commonplace the entity covers a small fraction of workers and establishments in construction. Perhaps unsurprisingly, the lowest presence of sectoral agreements is observed in industrial services, both with respect to establishments and employees covered. Firmlevel agreements are again sparse throughout, albeit with a higher-than-average presence in traffic and communications.

Finally, the 11-sector disaggregation is given in Table $3 \mathrm{~b}$. The data cover only the final three years of the study period and are not fully comparable with the previous seven-sector information. The material confirms the pattern observed earlier for 
Table 3a. Collective bargaining and works council coverage for Germany, 2000-2008, by sector, weighted data, in percentages.

\begin{tabular}{|c|c|c|c|c|c|c|c|c|c|}
\hline \multirow[b]{3}{*}{ Year } & \multirow[b]{3}{*}{ Sector } & \multicolumn{8}{|c|}{ Collective agreement status } \\
\hline & & \multicolumn{2}{|c|}{$\begin{array}{l}\text { Sectoral } \\
\text { agreement }\end{array}$} & \multicolumn{2}{|c|}{$\begin{array}{l}\text { Firm-level } \\
\text { agreement }\end{array}$} & \multicolumn{2}{|c|}{ No agreement } & \multicolumn{2}{|c|}{ Works council } \\
\hline & & 1 & II & 1 & II & I & II & 1 & II \\
\hline 2000 & Manufacturing & 45.9 & 63.9 & 4.1 & 7.0 & 49.9 & 29.1 & 16.8 & 65.4 \\
\hline 2001 & & 47.5 & 64.3 & 2.6 & 8.3 & 49.8 & 27.4 & 18.1 & 67.8 \\
\hline 2002 & & 46.5 & 66.2 & 2.3 & 6.9 & 51.2 & 26.9 & 16.1 & 70.1 \\
\hline 2003 & & 48.9 & 65.1 & 2.6 & 7.3 & 48.5 & 27.6 & 15.9 & 68.3 \\
\hline 2004 & & 44.5 & 63.5 & 3.2 & 6.8 & 52.3 & 29.6 & 14.8 & 66.9 \\
\hline 2005 & & 41.1 & 60.0 & 2.9 & 8.5 & 56.0 & 31.5 & 15.9 & 67.3 \\
\hline 2006 & & 40.1 & 58.1 & 3.0 & 9.6 & 56.9 & 32.3 & 15.9 & 67.0 \\
\hline 2007 & & 35.8 & 57.1 & 2.9 & 9.1 & 61.3 & 33.9 & 15.7 & 67.3 \\
\hline 2008 & & 36.3 & 55.7 & 3.2 & 9.8 & 60.5 & 34.6 & 14.9 & 67.7 \\
\hline Trend & & _**** & _**** & n.s. & $+* *$ & $+* * *$ & $+* * *$ & -** & n.s. \\
\hline 2000 & Construction & 68.8 & 73.6 & 3.2 & 4.2 & 28.1 & 22.3 & 6.3 & 27.5 \\
\hline 2001 & & 67.0 & 72.8 & 1.4 & 4.0 & 31.7 & 23.2 & 7.0 & 28.6 \\
\hline 2002 & & 70.1 & 75.6 & I.I & 2.3 & 28.8 & 22.1 & 6.0 & 24.6 \\
\hline 2003 & & 64.4 & 73.8 & 0.9 & 2.3 & 34.7 & 24.0 & 5.7 & 24.2 \\
\hline 2004 & & 64.7 & 70.9 & 0.9 & 2.9 & 34.4 & 26.2 & 4.5 & 22.2 \\
\hline 2005 & & 68.2 & 73.6 & 0.9 & 3.0 & 31.0 & 23.4 & 4.9 & 22.4 \\
\hline 2006 & & 65.5 & 72.8 & 0.7 & 2.1 & 33.8 & 25.0 & 4.0 & 18.4 \\
\hline 2007 & & 67.7 & 73.8 & 0.9 & 1.8 & 31.4 & 24.4 & 3.4 & 18.4 \\
\hline 2008 & & 65.6 & 72.1 & 0.7 & 2.6 & 33.6 & 25.2 & 2.4 & 16.9 \\
\hline Trend & & n.s. & n.s. & _** & _** & n.s. & $+* *$ & _*** & - *** \\
\hline 2000 & Trade and repair & 56.2 & 63.5 & 2.7 & 4.9 & 41.1 & 31.6 & 10.5 & 34.6 \\
\hline 2001 & & 57.8 & 66.9 & 1.9 & 4.1 & 40.4 & 29.0 & 10.8 & 36.8 \\
\hline 2002 & & 56.0 & 65.5 & 1.7 & 4.3 & 42.3 & 30.2 & 10.9 & 36.2 \\
\hline 2003 & & 55.3 & 64.5 & 2.1 & 5.2 & 42.5 & 30.3 & 10.2 & 35.0 \\
\hline 2004 & & 49.6 & 60.5 & 2.0 & 5.6 & 48.4 & 33.9 & 11.0 & 36.3 \\
\hline 2005 & & 44.4 & 56.5 & 2.3 & 5.3 & 53.3 & 38.2 & 10.6 & 34.2 \\
\hline 2006 & & 41.5 & 52.0 & 2.6 & 5.0 & 55.9 & 43.0 & 9.0 & 32.3 \\
\hline 2007 & & 40.9 & 50.0 & 2.4 & 5.5 & 56.7 & 44.5 & 8.8 & 32.4 \\
\hline 2008 & & 38.6 & 45.5 & 2.9 & 4.6 & 58.6 & 49.9 & 9.7 & 32.0 \\
\hline Trend & & _*** & _**** & n.s. & n.s. & $+* * *$ & $+* * *$ & -** & _** \\
\hline 2000 & $\begin{array}{l}\text { Traffic and } \\
\text { communications }\end{array}$ & 45.5 & 54.2 & 5.8 & 21.0 & 48.6 & 24.7 & 15.4 & 55.6 \\
\hline 2001 & & 42.6 & 51.8 & 9.4 & 23.4 & 47.9 & 24.9 & 19.7 & 57.8 \\
\hline 2002 & & 38.4 & 47.6 & 9.4 & 22.3 & 52.1 & 30.1 & 19.6 & 57.6 \\
\hline 2003 & & 43.7 & 50.7 & 5.7 & 22.3 & 50.7 & 27.0 & 21.7 & 58.1 \\
\hline 2004 & & 35.3 & 48.0 & 7.2 & 21.1 & 57.5 & 31.0 & 17.6 & 53.2 \\
\hline 2005 & & 35.3 & 46.7 & 7.0 & 19.9 & 57.8 & 33.3 & 17.5 & 52.1 \\
\hline 2006 & & 32.1 & 41.1 & 4.0 & 16.4 & 63.9 & 42.5 & 19.3 & 48.8 \\
\hline
\end{tabular}


Table 3a. (Continued)

\begin{tabular}{|c|c|c|c|c|c|c|c|c|c|}
\hline \multirow[b]{3}{*}{ Year } & \multirow[b]{3}{*}{ Sector } & \multicolumn{8}{|c|}{ Collective agreement status } \\
\hline & & \multicolumn{2}{|c|}{$\begin{array}{l}\text { Sectoral } \\
\text { agreement }\end{array}$} & \multicolumn{2}{|c|}{$\begin{array}{l}\text { Firm-level } \\
\text { agreement }\end{array}$} & \multicolumn{2}{|c|}{ No agreement } & \multicolumn{2}{|c|}{ Works council } \\
\hline & & I & II & 1 & II & I & II & 1 & II \\
\hline 2007 & & 32.6 & 40.8 & 3.0 & 11.8 & 64.3 & 47.4 & 15.9 & 43.7 \\
\hline 2008 & & 31.0 & 42.2 & 3.1 & 14.4 & 66.0 & 43.5 & 14.8 & 48.1 \\
\hline Trend & & -**** & -**** & -** & -**** & $+* * *$ & $+* * *$ & n.s. & $-* * *$ \\
\hline 2000 & $\begin{array}{l}\text { Banking and } \\
\text { insurance }\end{array}$ & 72.7 & 89.7 & 2.2 & 5.3 & 25.1 & 5.0 & 57.3 & 85.4 \\
\hline 2001 & & 68.4 & 89.5 & 0.8 & 4.7 & 30.8 & 5.9 & 46.8 & 84.8 \\
\hline 2002 & & 71.7 & 89.6 & 0.9 & 4.1 & 27.4 & 6.2 & 55.1 & 89.3 \\
\hline 2003 & & 71.2 & 86.7 & 3.1 & 6.0 & 25.7 & 7.3 & 42.4 & 83.6 \\
\hline 2004 & & 69.9 & 88.1 & 0.6 & 3.6 & 29.5 & 8.2 & 41.6 & 83.4 \\
\hline 2005 & & 74.1 & 91.0 & 1.0 & 2.0 & 25.0 & 7.0 & 48.0 & 84.7 \\
\hline 2006 & & 67.4 & 90.5 & 1.3 & 2.0 & 31.2 & 7.4 & 48.1 & 83.6 \\
\hline 2007 & & 69.0 & 90.3 & 5.4 & 3.5 & 25.6 & 6.3 & 51.4 & 86.7 \\
\hline 2008 & & 65.2 & 86.9 & 1.7 & 3.1 & 33.1 & 9.9 & 40.7 & 82.2 \\
\hline Trend & & n.s. & n.s. & n.s. & _** & n.s. & $+* *$ & n.s. & n.s. \\
\hline 2000 & $\begin{array}{l}\text { Industrial } \\
\text { services }\end{array}$ & 15.0 & 35.7 & 2.2 & 6.6 & 82.8 & 57.7 & 10.4 & 38.9 \\
\hline 2001 & & 12.4 & 32.9 & 2.2 & 6.7 & 85.4 & 60.3 & 7.7 & 34.3 \\
\hline 2002 & & 11.4 & 29.6 & 1.6 & 5.1 & 87.0 & 65.4 & 6.1 & 32.7 \\
\hline 2003 & & 13.6 & 29.6 & 1.4 & 4.7 & 85.0 & 65.7 & 6.1 & 29.3 \\
\hline 2004 & & 14.2 & 32.4 & 1.4 & 7.5 & 84.4 & 60.1 & 7.2 & 32.1 \\
\hline 2005 & & 12.6 & 35.7 & 1.6 & 6.2 & 85.7 & 58.1 & 7.2 & 30.7 \\
\hline 2006 & & 14.1 & 34.7 & 1.6 & 7.0 & 84.3 & 58.3 & 7.7 & 31.4 \\
\hline 2007 & & 14.6 & 38.3 & 1.7 & 6.2 & 83.7 & 55.6 & 7.7 & 29.0 \\
\hline 2008 & & 14.1 & 36.6 & 1.8 & 6.8 & 84.0 & 56.7 & 7.4 & 27.9 \\
\hline Trend & & n.s. & n.s. & n.s. & n.s. & n.s. & n.s. & n.s. & _**** \\
\hline 2000 & Other services & 46.4 & 47.4 & 2.7 & 6.8 & 50.9 & 45.7 & 6.3 & 28.8 \\
\hline 2001 & & 42.3 & 50.3 & 3.3 & 5.7 & 54.4 & 43.9 & 5.4 & 30.5 \\
\hline 2002 & & 41.4 & 47.2 & 3.1 & 7.7 & 55.4 & 45.1 & 4.8 & 28.4 \\
\hline 2003 & & 39.8 & 48.9 & 2.2 & 6.5 & 58.0 & 44.6 & 5.0 & 29.0 \\
\hline 2004 & & 37.9 & 47.0 & 2.4 & 5.8 & 59.7 & 47.1 & 4.4 & 27.3 \\
\hline 2005 & & 40.8 & 47.0 & 2.5 & 6.1 & 56.7 & 46.9 & 5.4 & 28.9 \\
\hline 2006 & & 36.6 & 46.0 & 1.7 & 6.2 & 61.7 & 47.9 & 4.7 & 29.5 \\
\hline 2007 & & 33.0 & 42.9 & 2.4 & 7.0 & 64.6 & 50.2 & 4.3 & 29.7 \\
\hline 2008 & & 34.1 & 44.3 & 2.5 & 7.1 & 63.4 & 48.5 & 4.7 & 29.9 \\
\hline Trend & & -**** & -** & n.s. & n.s. & $+* * *$ & $+* * *$ & -** & n.s. \\
\hline
\end{tabular}

Notes: I denotes the proportion of establishments and II the proportion of employees. ***, **, and * denote statistical significance at the $.01, .05$, and .10 levels, respectively. 
Table 3b. Collective bargaining and works council coverage for Germany, 2009-20I I, by sector, weighted data, in percentages.

\begin{tabular}{|c|c|c|c|c|c|c|c|c|c|}
\hline \multirow[b]{3}{*}{ Year } & \multirow[b]{3}{*}{ Sector } & \multicolumn{8}{|c|}{ Collective agreement status } \\
\hline & & \multicolumn{2}{|c|}{$\begin{array}{l}\text { Sectoral } \\
\text { agreement }\end{array}$} & \multicolumn{2}{|c|}{$\begin{array}{l}\text { Firm-level } \\
\text { agreement }\end{array}$} & \multicolumn{2}{|c|}{$\begin{array}{l}\text { No } \\
\text { agreement }\end{array}$} & \multicolumn{2}{|c|}{$\begin{array}{l}\text { Works } \\
\text { council }\end{array}$} \\
\hline & & I & II & I & II & I & II & I & II \\
\hline 2009 & Manufacturing & 36.6 & 54.8 & 4.0 & 9.1 & 59.3 & 36.1 & 15.0 & 66.4 \\
\hline 2010 & & 32.5 & 52.9 & 4.0 & 10.7 & 63.5 & 36.4 & 15.7 & 66.6 \\
\hline 2011 & & 31.4 & 51.8 & 3.9 & 9.5 & 64.8 & 38.7 & 15.7 & 65.9 \\
\hline 2009 & Construction & 69.3 & 73.4 & 0.9 & 2.5 & 29.7 & 24.1 & 3.3 & 19.0 \\
\hline 2010 & & 64.2 & 70.7 & 1.0 & 2.6 & 34.7 & 26.8 & 3.4 & 21.0 \\
\hline 2011 & & 60.1 & 66.0 & 0.8 & 3.2 & 39.1 & 30.7 & 3.1 & 16.6 \\
\hline 2009 & Trade & 39.2 & 46.5 & 3.2 & 5.9 & 57.6 & 47.6 & 9.6 & 33.1 \\
\hline 2010 & & 37.2 & 46.7 & 2.3 & 4.2 & 60.5 & 49.2 & 9.7 & 32.2 \\
\hline 2011 & & 33.7 & 43.3 & 2.1 & 3.9 & 64.2 & 52.7 & 10.0 & 30.4 \\
\hline 2009 & Traffic and warehousing & 27.9 & 38.7 & 3.4 & 17.9 & 68.6 & 43.4 & 15.3 & 51.6 \\
\hline 2010 & & 25.5 & 36.6 & 5.8 & 14.1 & 68.7 & 49.3 & 11.6 & 43.7 \\
\hline 2011 & & 23.8 & 41.7 & 4.6 & 12.9 & 71.6 & 45.4 & 11.8 & 48.7 \\
\hline 2009 & $\begin{array}{l}\text { Information and } \\
\text { communications }\end{array}$ & 9.8 & 20.4 & 1.3 & 6.9 & 88.9 & 72.8 & 13.2 & 44.0 \\
\hline 2010 & & 9.5 & 25.8 & 1.7 & 3.7 & 88.8 & 70.5 & 15.0 & 48.1 \\
\hline 2011 & & 8.1 & 16.5 & 2.1 & 3.6 & 89.8 & 79.9 & 12.8 & 43.5 \\
\hline 2009 & Hotels and gastronomy & 35.1 & 46.2 & 1.6 & 3.8 & 63.3 & 50.0 & 2.1 & 9.5 \\
\hline 2010 & & 38.5 & 51.1 & 1.2 & 2.4 & 60.3 & 46.5 & 2.3 & 10.5 \\
\hline 2011 & & 32.4 & 45.1 & 2.3 & 2.6 & 65.3 & 52.3 & 2.9 & 8.6 \\
\hline 2009 & $\begin{array}{l}\text { Financial and insurance } \\
\text { services }\end{array}$ & 70.8 & 89.3 & 1.3 & 2.2 & 27.9 & 8.5 & 46.0 & 84.4 \\
\hline 2010 & & 63.0 & 84.9 & 1.9 & 2.1 & 35.2 & 13.0 & 38.2 & 81.0 \\
\hline 2011 & & 56.3 & 82.6 & 1.1 & 1.9 & 42.7 & 15.5 & 34.5 & 78.3 \\
\hline 2009 & $\begin{array}{l}\text { Commercial, scientific, } \\
\text { and professional } \\
\text { services }\end{array}$ & 16.4 & 42.0 & 2.1 & 8.4 & 81.5 & 49.6 & 6.4 & 27.8 \\
\hline 2010 & & 17.5 & 46.7 & 1.7 & 6.5 & 80.7 & 46.9 & 7.2 & 30.9 \\
\hline 2011 & & 18.3 & 46.9 & 1.8 & 4.4 & 79.9 & 48.7 & 6.9 & 26.9 \\
\hline 2009 & Education & 8.1 & 10.5 & 18.0 & 23.8 & 73.9 & 65.7 & 10.8 & 25.7 \\
\hline 2010 & & 4.8 & 10.6 & 12.1 & 17.4 & 83.1 & 72.0 & 13.6 & 34.8 \\
\hline 2011 & & 9.0 & 6.1 & 11.7 & 28.3 & 79.4 & 65.6 & 14.8 & 35.7 \\
\hline 2009 & Health and social care & 29.2 & 39.3 & 2.0 & 12.0 & 68.8 & 48.6 & 4.8 & 42.3 \\
\hline 2010 & & 27.5 & 40.6 & 2.7 & 10.6 & 69.8 & 48.8 & 6.1 & 40.1 \\
\hline 2011 & & 26.8 & 38.5 & 3.1 & 12.8 & 70.1 & 48.8 & 5.3 & 41.0 \\
\hline 2009 & Other services & 42.8 & 39.9 & 1.0 & 5.0 & 56.2 & 55.0 & 5.0 & 25.2 \\
\hline 2010 & & 33.7 & 33.7 & 0.5 & 3.6 & 65.8 & 62.7 & 6.3 & 23.8 \\
\hline 2011 & & 45.5 & 36.2 & 0.8 & 4.1 & 53.7 & 59.8 & 4.9 & 18.1 \\
\hline
\end{tabular}

Note: I denotes the proportion of establishments and II the proportion of employees. 
manufacturing, construction, and banking and insurance. Comparisons across the other sectors are more difficult because of the greater disaggregation of services in Table 3 , but the limited collective bargaining presence in two sectors - information and communications and education - is notable particularly with respect to establishment coverage at less than $10 \%$. Note that the low coverage of education is hardly surprising since only establishments from the private sector are retained in our sample.

Now there are some marked regional differences in the coverage and course of collective bargaining and worker representation across Germany. In the east, sectoral bargaining coverage by establishments is markedly lower than in the west but has declined less, although the downward trends in both cases are statistically significant (see Appendix Table A1). In the west, equal numbers of establishments had no collective bargaining as had sectoral agreements by 2003. If anything, firm-level bargaining is more entrenched in the east, although there is a statistically significant decline in coverage. Establishments without collective bargaining of any type more clearly dominate in the east. As of 2000, for example, $66.8 \%$ of establishments in eastern Germany compared with $44.7 \%$ in western Germany had no collective agreement. That said, the growth of this bargaining-free sector has been much smaller - though no less statistically significant - in the east. By 2011, coverage of the bargaining-free sector in eastern Germany had risen to $76.3 \%$, as compared with $61.8 \%$ in western Germany. On the other hand, both the incidence and pattern of decline in the share of plants with works councils is very similar in the two broad regions and the trends well determined in each. It is also fair to say that much the same patterns by broad region are evident in the coverage of collective bargaining and worker representation by employee data (compare west and east in columns II of Appendix Table A1).

It is of course possible to present a finer breakdown of coverage by individual federated state (Bundesland). For example, Ellguth and Kohaut (2013: 284) examine the coverage of sectoral agreements by employment in 2012 for 15 of the 16 German states (Länder) - Schleswig-Holstein being combined on this occasion with Hamburg. Their data indicate that the share of employees covered by sectoral agreements in west German states ranged from 51 to $58 \%$ with the exception of one outlier (Schleswig-HolsteinHamburg at 45\%). In eastern Germany, no state has as high a share and the actual range is smaller: from 33\% in Mecklenburg-Vorpommern to 39\% in Brandenburg. The same pattern in reverse is found for the uncovered sector; now the range is from 36 to $45 \%$ in the west and from 48 to $55 \%$ in the east.

Next, as far as the joint presence of works councils and sectoral collective bargaining is concerned, there is further evidence of erosion. These results are summarized in Table 4. At the start of our period, $7.8 \%$ (35.4\%) of establishments (employees) were covered by sectoral agreements and works councils whereas 11 years later only $5.8 \%(28.0 \%)$ of establishments (employees) were in that position. Each trend was statistically significant, pointing more directly to an attenuation of the dual system. ${ }^{10}$ Interestingly, the distribution of works councils by sectoral agreement is largely unchanged between 2000 and 2011. At the start of our sample period, $16.4 \%$ of plants following sectoral agreements had works councils. In 2011, the proportion was $17.6 \%$. The corresponding employment shares were also very close at $59.8 \%$ and $58.6 \%$, respectively. Clearly, the decline in the dual system is driven by the fact that sectoral agreements are losing momentum, not by a particularly strong decrease in the presence of works councils. 
Interestingly, works council presence in the burgeoning collective bargaining free sector, albeit sparse to begin with, displays only a modest decline over the sample period. Specifically, the share of plants with works councils but no collective agreements in the firmament of plants without collective bargaining fell from $4.9 \%$ to $3.3 \%$ of all such establishments and from $19.0 \%$ to $18.3 \%$ of employment in all such establishments. That said, the share of establishments/employees without either a collective agreement or works councils in the entire sample covered rose substantially. ${ }^{11}$

Finally, although opening clauses and pacts are peripheral themes of this empirical inquiry, it is interesting to address the links between works councils and these contractual innovations, not least because many observers see works council presence as central to the issue of whether internal erosion is organized or destabilizing. However, data limitations loom large here. That is, the relevant data on pacts pertain to 2006, 2008, and 2009, while for opening clauses the available years are 2005, 2007, and 2011. In short, in any such inquiry, we are constrained to use just three layers of cross-sectional data, with no possibility of providing series for 2000-2011 as in the case of other variables considered here. Subject to this important lacuna, we provide weighted statistics at both establishment and employee level on coverage by type of innovation and workplace representation in Table 5.

Beginning with pacts for employment and competitiveness in panel (a) of the table, we observe firstly a modest increase in their extent over the 2006-2009 interval, namely from 13.7 to $15.0 \%$ in terms of employee coverage and from 2.3 to $2.6 \%$ in terms of establishment coverage. More interesting perhaps is the finding that although the presence of works councils in establishments without pacts appears very stable, in the case of establishments with pacts reductions in works council coverage of 4.6 percentage points for employment and 11.4 percentage points in establishment coverage are recorded over the period. As a practical matter, however, the importance of works councils in regimes with pacts is manifest, especially in large establishments.

Turning to the presence of opening clauses in collective agreements, shown in panel (b) of the table, there is evidence of an overall increase in coverage of between 10 and 13 percentage points over the period in question (2005-2011). As expected, the incidence of works councils is higher in establishments covered by agreements with opening clauses than in plants without them, and by a wide margin, but in both cases the tendency is to observe proportionally fewer works councils in 2011 than 2005. Panel (c) of the table documents the application of opening clauses (as opposed to their existence), and usage can be seen to have grown through time. However, among the firmament of plants using opening clauses those with works councils have shrunk in terms of their employment and establishment coverage, most obviously along the former dimension.

The bottom line of this necessarily preliminary inquiry is that although contract innovations and works councils are intimately related, works council presence is diminishing here as well. There is little indication that the pronounced increase in the use of opening clauses has stimulated works councils since their relative incidence is little affected by activation or non-activation. And as far as pacts are concerned, although works councils are even more dominant, as indexed by their majority employment and establishment coverage, their incidence has unambiguously declined both in employee and employer shares. Alternatively put, the incidence of plants without a works council has grown in the cases of opening clauses and pacts. If innovations are flourishing, the fact remains that works council presence is diminishing. Their decline is admittedly modest but pre- 
Table 4. Collective agreement and works council coverage in 2000 and $20 \mathrm{I}$, weighted data, in percentages.

\begin{tabular}{|c|c|c|c|c|}
\hline & \multicolumn{2}{|l|}{2000} & \multicolumn{2}{|l|}{2011} \\
\hline & Establishments & Employees & Establishments & Employees \\
\hline $\begin{array}{l}\text { Establishments/employees } \\
\text { covered by works councils and } \\
\text { sectoral collective bargaining in } \\
\text { the entire sample } \\
{[(\text { scb\&woco)]/total }}\end{array}$ & 7.8 & 35.4 & 5.8 & 28.0 \\
\hline $\begin{array}{l}\text { Establishments/employees } \\
\text { covered by sectoral collective } \\
\text { bargaining but without works } \\
\text { councils in the entire sample } \\
\text { [(scb\&nowoco)]/total }\end{array}$ & 40.0 & 23.8 & 27.1 & 19.8 \\
\hline $\begin{array}{l}\text { Establishments/employees } \\
\text { covered by works councils and } \\
\text { firm-level agreements in the } \\
\text { entire sample } \\
{[(\text { fcb\&woco })] / \text { total }}\end{array}$ & 1.2 & 5.9 & 1.4 & 6.2 \\
\hline $\begin{array}{l}\text { Establishments/employees } \\
\text { covered by firm-level } \\
\text { agreements but without works } \\
\text { councils in the entire sample } \\
{[(\text { fcb\&nowoco })] / \text { total }}\end{array}$ & 1.9 & 1.4 & I.I & 1.0 \\
\hline $\begin{array}{l}\text { Establishments/employees } \\
\text { covered by works councils and } \\
\text { sectoral collective bargaining } \\
\text { in the sectoral agreements } \\
\text { sample } \\
\text { [(scb\&woco)]/total scb }\end{array}$ & 16.4 & 59.8 & 17.6 & 58.6 \\
\hline $\begin{array}{l}\text { Establishments/employees with } \\
\text { works councils but without } \\
\text { collective bargaining in the no } \\
\text { collective agreement sample } \\
\text { [(nocb\&woco)]/total nocb }\end{array}$ & 4.9 & 19.0 & 3.3 & 18.3 \\
\hline $\begin{array}{l}\text { Establishments/employees } \\
\text { without collective bargaining } \\
\text { and without works councils } \\
\text { in the entire sample } \\
{[(\text { nocb\&nowoco }] / \text { total }}\end{array}$ & 46.6 & 27.2 & 62.5 & 36.8 \\
\hline
\end{tabular}

sumably any revitalization of the dual system would imply a growth in contractual innovation and a growth in works council presence. Yet we do not observe this in the data.

Permanents stayers, newly-founded and failing establishments. Figures 2 through 4 examine the same body of evidence considered earlier but this time for different types of firms. This material is complemented by information in tabular form in Appendix Tables A2 through 
Table 5. Company-level pacts, the existence and application of opening clauses, and works council presence, weighted data, in percentages.

(a) Company-level pacts (CLP).

\begin{tabular}{|c|c|c|c|c|c|c|}
\hline & & \multirow[t]{2}{*}{$\begin{array}{l}\text { CLP (\% in } \\
\text { the total) }\end{array}$} & \multicolumn{2}{|c|}{$\begin{array}{l}\text { Establishments and } \\
\text { employees without } \\
\text { CLP }\end{array}$} & \multicolumn{2}{|c|}{$\begin{array}{l}\text { Establishments and } \\
\text { employees with CLP }\end{array}$} \\
\hline & & & $\begin{array}{l}\text { Without } \\
\text { works } \\
\text { councils }\end{array}$ & $\begin{array}{l}\text { With } \\
\text { works } \\
\text { councils }\end{array}$ & $\begin{array}{l}\text { Without } \\
\text { works } \\
\text { councils }\end{array}$ & $\begin{array}{l}\text { With } \\
\text { works } \\
\text { councils }\end{array}$ \\
\hline \multirow[t]{2}{*}{2006} & Employees & 13.7 & 63.0 & 37.0 & 5.0 & 95.0 \\
\hline & Establishments & 2.3 & 91.7 & 8.3 & 35.2 & 64.8 \\
\hline \multirow[t]{2}{*}{2008} & Employees & 13.8 & 63.5 & 36.5 & 9.0 & 91.0 \\
\hline & Establishments & 2.5 & 92.1 & 7.9 & 45.3 & 54.7 \\
\hline \multirow[t]{2}{*}{2009} & Employees & 15.0 & 63.3 & 36.7 & 9.6 & 90.4 \\
\hline & Establishments & 2.6 & 91.8 & 8.2 & 46.6 & 53.4 \\
\hline
\end{tabular}

(b) Opening clauses (in establishments bound by a collective agreement).

\begin{tabular}{|c|c|c|c|c|c|c|}
\hline & & \multirow[t]{2}{*}{$\begin{array}{l}\text { Opening clauses } \\
\text { (\% in the total) }\end{array}$} & \multicolumn{2}{|c|}{$\begin{array}{l}\text { Establishments and } \\
\text { employees without } \\
\text { opening clauses }\end{array}$} & \multicolumn{2}{|c|}{$\begin{array}{l}\text { Establishments and } \\
\text { employees with } \\
\text { opening clauses }\end{array}$} \\
\hline & & & $\begin{array}{l}\text { Without } \\
\text { works } \\
\text { councils }\end{array}$ & $\begin{array}{l}\text { With works } \\
\text { councils }\end{array}$ & $\begin{array}{l}\text { Without } \\
\text { works } \\
\text { councils }\end{array}$ & $\begin{array}{l}\text { With works } \\
\text { councils }\end{array}$ \\
\hline \multirow[t]{2}{*}{2005} & Employees & 39.7 & 41.5 & 58.5 & 18.7 & 81.3 \\
\hline & Establishments & 20.9 & 81.6 & 18.4 & 69.4 & 30.6 \\
\hline \multirow[t]{2}{*}{2007} & Employees & 43.6 & 46.7 & 53.3 & 18.6 & 81.4 \\
\hline & Establishments & 21.2 & 85.1 & 14.9 & 67.0 & 33.0 \\
\hline \multirow[t]{2}{*}{2011} & Employees & 52.7 & 50.3 & 49.7 & 23.6 & 76.4 \\
\hline & Establishments & 31.2 & 82.1 & 17.9 & 72.6 & 27.4 \\
\hline
\end{tabular}

A4. Beginning with those plants that were present in each wave of the sample period namely, permanent stayers - the coverage by establishment data summarized in panel (a) of Figure 2 resembles that reported earlier for the full sample. (This is not simply true for the all-German case but also for eastern and western Germany as well.) Thus, for Germany as a whole, sectoral bargaining coverage by establishment declined from $48.2 \%$ in 2000 to $40.2 \%$ in 2011, and the share of establishments without collective bargaining of any sort rose from $46.8 \%$ to $57.1 \%$, somewhat less marked than is the case for the cross-sectional data. Works council coverage actually increased. In all of these cases, the annual trend was statistically significant. On the other hand, we observe a broadly similar stability in firmlevel collective bargaining coverage (i.e. no trend at the .05 level or better). There are no major differences at broad regional level, other than a lack of discernible trends for sectoral bargaining and works councils in eastern Germany. Although some differences emerge from 


\section{(c) Use of opening clauses (in establishments bound by a collective agreement containing opening clauses).}

\begin{tabular}{|c|c|c|c|c|c|c|}
\hline & & \multirow[t]{2}{*}{$\begin{array}{l}\text { Use of opening } \\
\text { clauses (\% in the } \\
\text { total) }\end{array}$} & \multicolumn{2}{|c|}{$\begin{array}{l}\text { Establishments and } \\
\text { employees with no use } \\
\text { of opening clauses }\end{array}$} & \multicolumn{2}{|c|}{$\begin{array}{l}\text { Establishments and } \\
\text { employees with use of } \\
\text { opening clauses }\end{array}$} \\
\hline & & & $\begin{array}{l}\text { Without } \\
\text { works } \\
\text { councils }\end{array}$ & $\begin{array}{l}\text { With works } \\
\text { councils }\end{array}$ & $\begin{array}{l}\text { Without } \\
\text { works } \\
\text { councils }\end{array}$ & $\begin{array}{l}\text { With works } \\
\text { councils }\end{array}$ \\
\hline \multirow[t]{2}{*}{2005} & Employees & 52.9 & 18.8 & 81.2 & 18.7 & 81.3 \\
\hline & Establishments & 57.1 & 65.8 & 34.2 & 72.2 & 27.8 \\
\hline \multirow[t]{2}{*}{2007} & Employees & 54.3 & 19.4 & 80.6 & 17.9 & 82.1 \\
\hline & Establishments & 52.4 & 65.8 & 34.2 & 68.2 & 31.8 \\
\hline \multirow[t]{2}{*}{2011} & Employees & 77.0 & 21.5 & 78.5 & 24.7 & 75.3 \\
\hline & Establishments & 75.1 & 72.9 & 27.1 & 73.3 & 26.7 \\
\hline
\end{tabular}

panel (b) of Figure 2, where we consider coverage by employment, the same results still stand. Firm-level agreements are somewhat more important in the east than before, while the trend increase is statistically significant in the west.

Figure 3 turns to newly-founded establishments and again presents coverage data for Germany as a whole. It is clear that sectoral (if not firm-level) bargaining is less pervasive among newly-founded establishments and remains so. Thus, the establishment (employment) coverage of sectoral agreements stood at $33.8 \%$ (39.0\%) in 2000 and was $29.2 \%$ $(39.4 \%)$ in 2010 . The corresponding values for the collective bargaining free sector also displayed only modest change - from $64.0 \%(55.5 \%)$ and $68.2 \%(53.9 \%)$. For its part, firm-level bargaining recorded slight increases for both coverage measures. Interestingly, works council employment coverage receded, from $34.0 \%$ in 2000 to $27.5 \%$ in 2010 . But none of these trends was statistically significant (at the .05 level or better) other than for the bargaining-free zone (the establishment coverage measure alone) and works councils (employment coverage). That said, there were some differences between the two halves of Germany in annual trends and their signs. The major difference, however, is again the much lower coverage of sectoral bargaining in eastern Germany (see Appendix Table A3).

Finally, Figure 4 summarizes the situation for firm deaths. In particular, the trends observed in respect of failing establishments more closely match those of the full sample. Thus, their sectoral agreement coverage by establishment (employment) fell from $48.6 \%$ $(55.1 \%)$ in 2000 to $31.9 \%(42.2 \%)$ in 2009 . The corresponding increases for failing plants without any collective bargaining were from $48.2 \%$ (36.6\%) in 2000 to $65.3 \%$ $(51.6 \%)$ in 2009. (In all four cases the trend is statistically significant.) In line with the full sample, works council coverage among failing plants also trended down significantly on both measures. On the other hand, the negative time trends in respect of local bargaining developments among failing firms are not statistically significant.

In sum, there are more similarities than dissimilarities among the different samples examined here in terms of the course of bargaining and worker representation over time in continuing and failing establishments. But if absence of coverage by any type of 


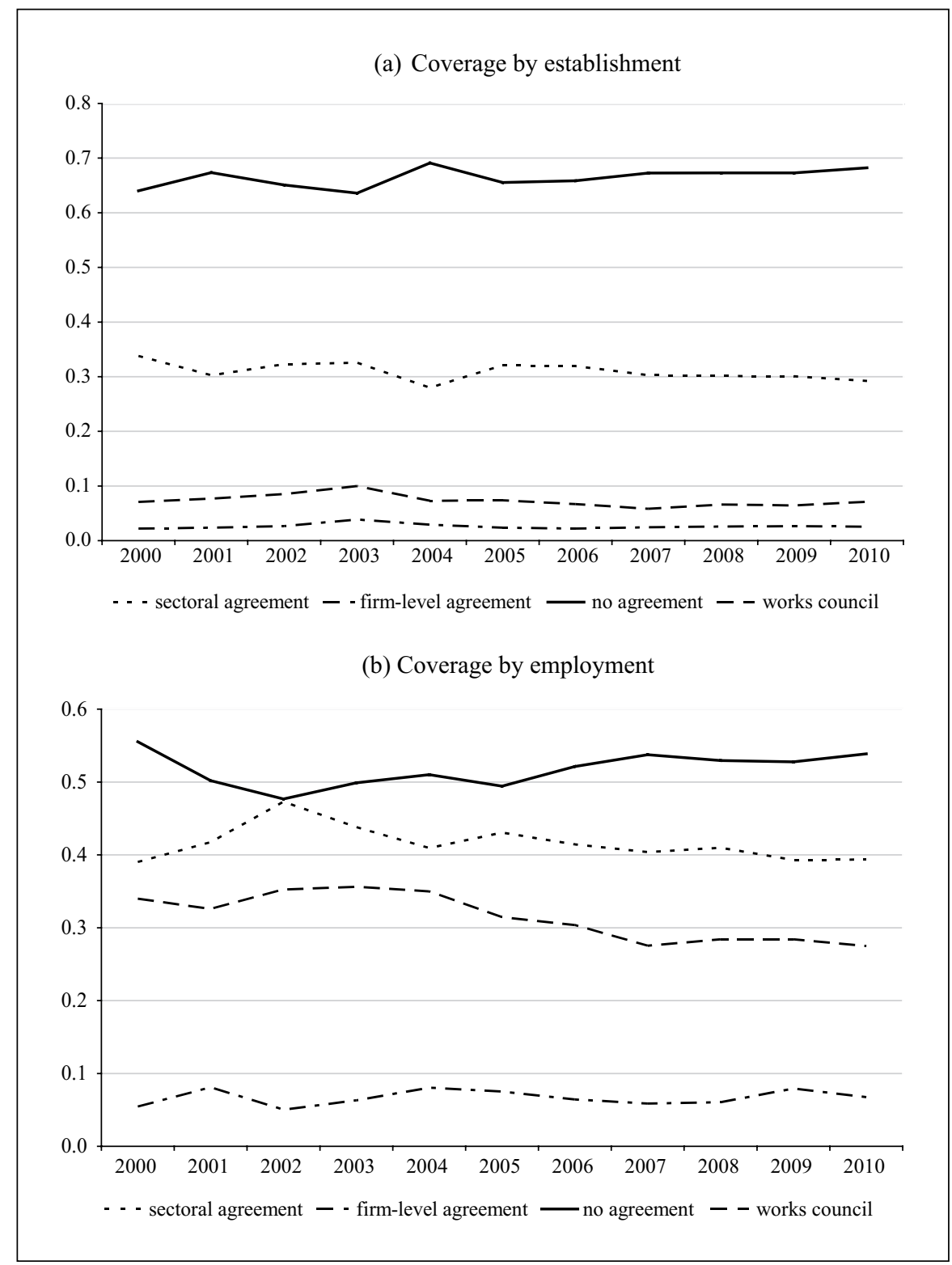

Figure 3. Collective bargaining and works council coverage in newly-founded establishments (i.e. births), Germany, 2000-2010 (establishments with at least five employees, cross-section weighted data).

collective agreement is persistently higher among newly-founded establishments (always above $60 \%$ over the period in terms of establishment coverage) than in their failing counterparts observe also that this self-same regime tends to be dominant (and increasingly 


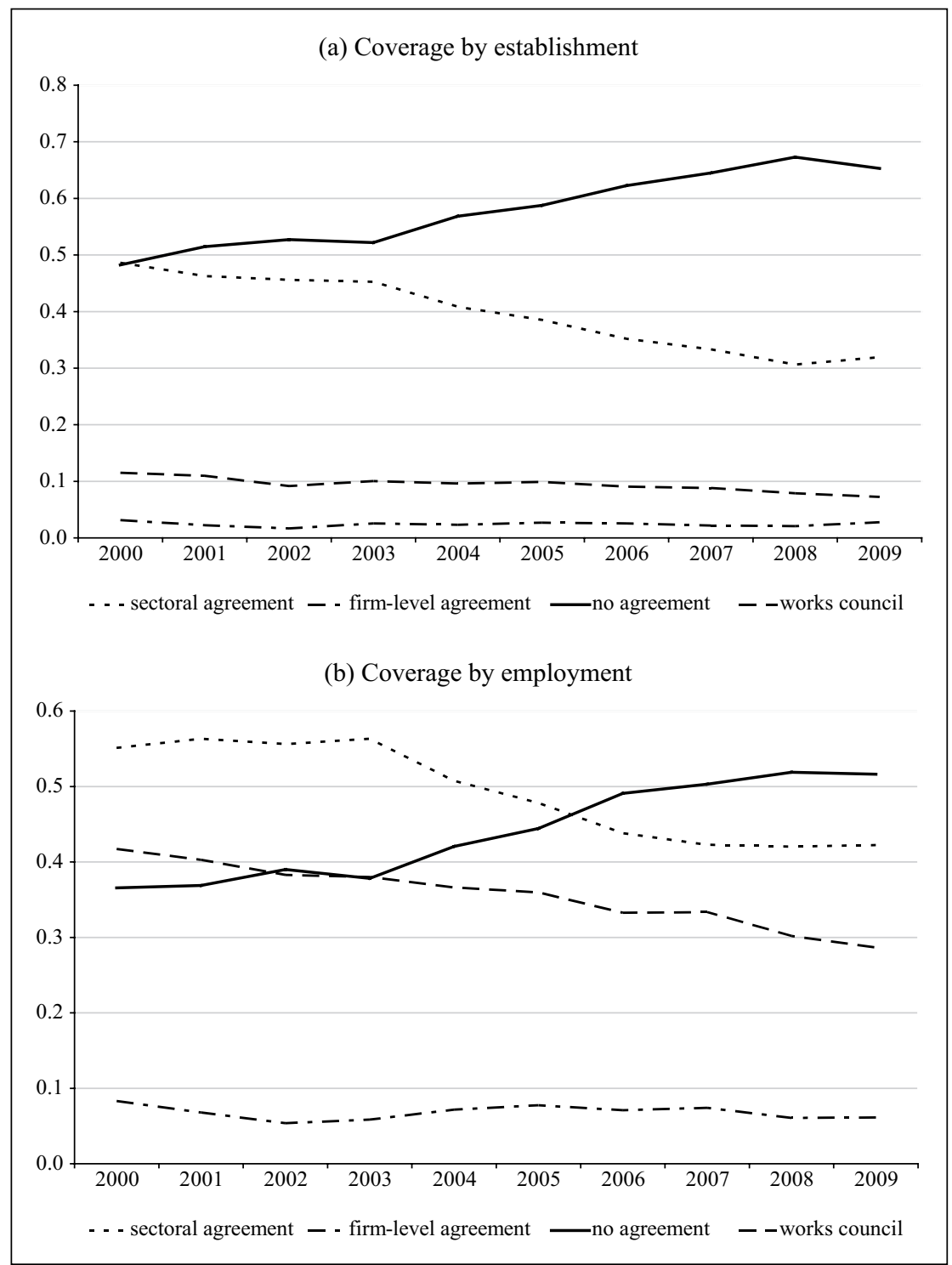

Figure 4. Collective bargaining and works council coverage among closing establishments (i.e. deaths), Germany, 2000-2008 (establishments with at least five employees, cross-section weighted data).

so) among the failing establishments, both in terms of establishment and employment coverage. It seems therefore safe to conclude that the observed decline in sectoral bargaining in the German private sector is mostly due to transitions from sectoral agreements to no agreements among existing establishments (see below). ${ }^{12}$ In turn, the 
evidence that closings are mostly from the no agreement sector suggests quite strongly that collective bargaining is itself not a cause of failure.

\section{Transitions data}

We next consider establishment transitions in respect of collective bargaining institutions and the works council entity. Whereas we earlier traced institutional status in successive crosssections, we now consider individual changes in status using overlapping cross-sections.

Annual transitions, all establishments. Annual transitions are given in Table 6 for 11 overlapping cross-sections. We consider 'introductions,' 'abolitions,' and maintenance of the status quo ante (namely situations in which the particular institution had either 'always existed' or 'never existed'). Beginning with sectoral bargaining, we see that by the end of 2001 no fewer than $90.3 \%$ of all establishments in Germany maintained their initial status, that is, in $44.5 \%$ (45.8\%) of the cases the sectoral agreement was always (never) present. By the end of the sample period, roughly the same share of plants recorded no change in status (i.e. 94.8\%). Alternatively put, 5-10\% of all establishments change their sectoral collective bargaining status over the course of a year, a not inconsiderable amount of churning. Note also that while $44.5 \%$ of the entire cross-section was covered by a sectoral agreement in 2000 and 2001, by the end of the sample period just $31.6 \%$ of all firms observed in 2010 and 2011 had sectoral bargaining in both years, confirming the evidence presented earlier. The fall in sectoral agreements is continuous except for 2002-2003 and 2009-2010. A reverse pattern obtains in respect of those plants never covered by a sectoral agreement: these climb from $45.8 \%$ of the total in the first column to $63.2 \%$ in the last column of Table 6 .

Firm-level agreements seemingly have a tenuous hold, with around $97 \%$ of establishments never being covered by this regime in the overlapping cross-sections. Correspondingly, changes in firm-level collective bargaining appear tiny. But recall that all values in Table 6 are expressed as proportions of all establishments, so that there is in fact evidence of not inconsiderable fluidity. For their part, works councils are present in roughly $9 \%$ of all establishments. Since their measured net changes in status resemble those for firm-level agreements, it follows that transitions are of lower frequency for works councils.

Regional differences are most marked in the case of sectoral collective bargaining. The share of 'never existing' agreements is much higher in eastern Germany by more than a 20 percentage point margin. Also note that the introduction of firm-level agreements is always higher (with one exception) in the east. But regional differences in transitions in the case of works councils are altogether more muted. ${ }^{13}$

Eleven-year transitions, permanent stayers. We also calculated transitions over the full sample period for permanent stayers. The main results of this exercise are presented in Table 7 and are as follows. First, almost one establishment in four either leaves or joins a sectoral agreement, the former route predominating by about three to one. Second, changes in works council status are a modest $4.6 \%$ of all transitions. Third, even if firm-level bargaining is sparse, transitions are extensive; in particular, over $80 \%$ of firm agreements 


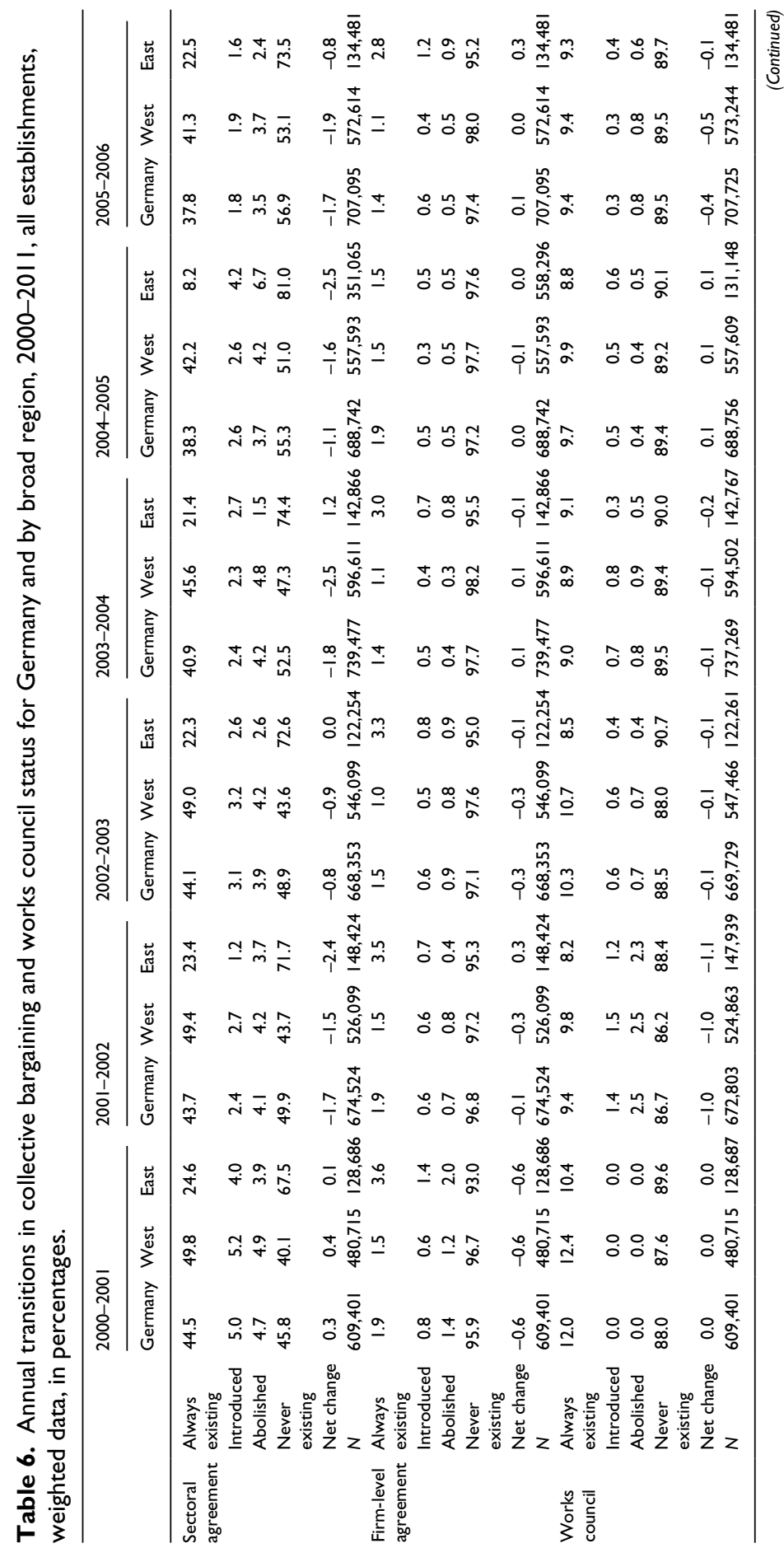




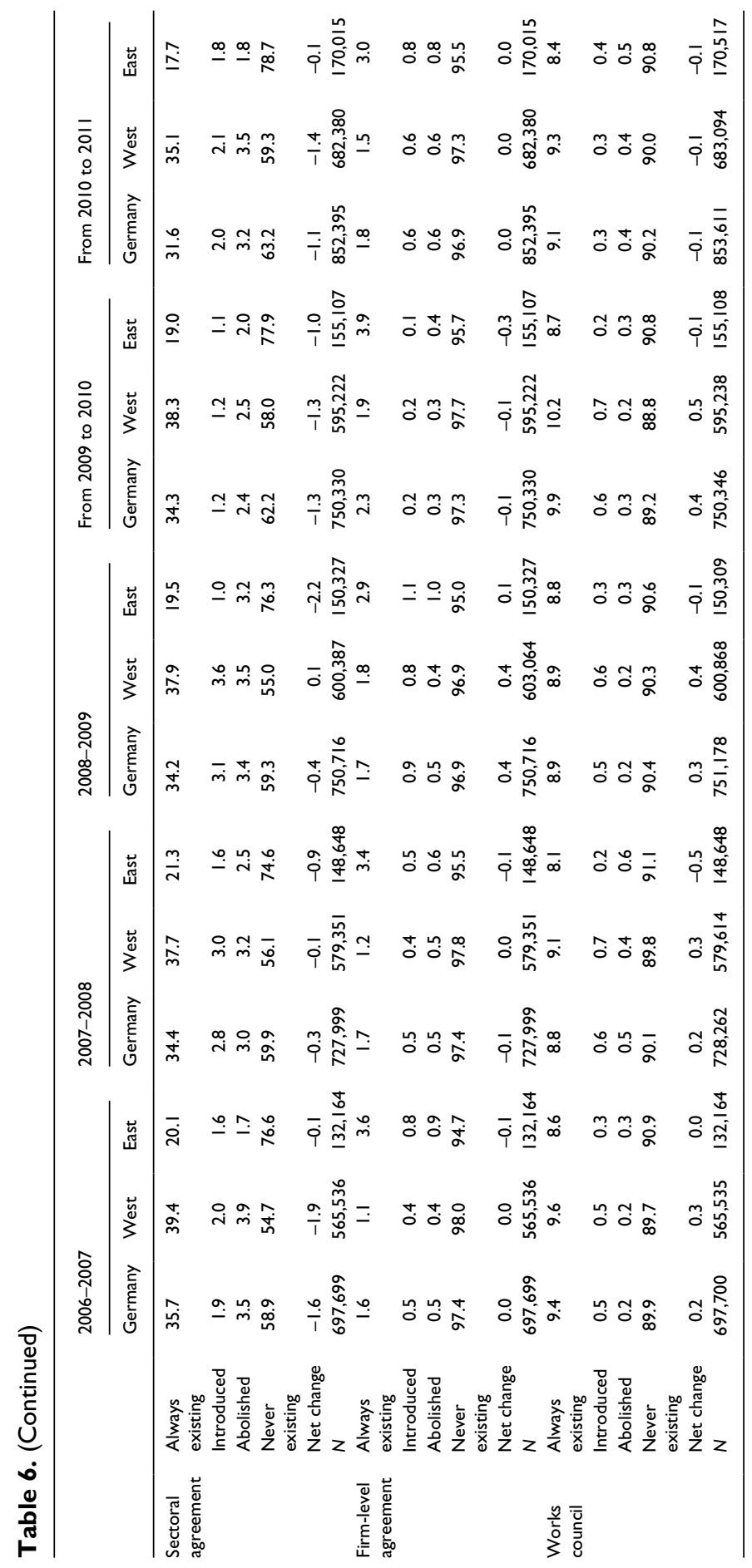


Table 7. Eleven-year transitions in collective bargaining and works council status for Germany and by broad region, 2000-201 I, permanent stayers, weighted data, in percentages.

\begin{tabular}{llcrc}
\hline & & Germany & West & East \\
\hline Sectoral agreement & Always existing & 30.1 & 35.3 & 14.3 \\
& Introduced & 6.2 & 7.0 & 3.6 \\
& Abolished & 18.1 & 20.5 & 10.8 \\
& Never existing & 45.6 & 37.3 & 71.3 \\
& Net change & -11.9 & -13.5 & -7.2 \\
& $N$ & 125,301 & 94,510 & 30,792 \\
Firm-level agreement & Always existing & 0.8 & 0.3 & 2.4 \\
& Introduced & 1.0 & 0.9 & 1.4 \\
& Abolished & 4.2 & 4.4 & 3.4 \\
& Never existing & 94.0 & 94.3 & 92.8 \\
& Net change & -3.1 & -3.5 & -2.0 \\
& $N$ & 125,301 & 94,510 & 30,792 \\
& Always existing & 7.5 & 6.9 & 9.4 \\
& Introduced & 2.0 & 2.5 & 0.7 \\
& Abolished & 2.6 & 1.8 & 4.9 \\
& Never existing & 87.9 & 88.8 & 85.1 \\
& Net change & -0.5 & 0.7 & -4.2 \\
& $N$ & 125,301 & 94,510 & 30,792 \\
\hline
\end{tabular}

will be terminated. Finally, western Germany records greater proportionate transitions in sectoral bargaining than does eastern Germany.

\section{A note on the role of outsourcing}

As a final exercise, we address the possibility of collective bargaining coverage being connected to changes in outsourcing intensity. To this end we use a specific IAB survey question inquiring of the manager respondent whether the establishment increased its purchases of products/services from outside sources over the course of the preceding two years. This variable is coded as a 1/0 dummy variable and is available in the 2000, 2001, 2004, 2007, and 2010 surveys. Given that we do not observe collective bargaining status in either 1998 or 1999 (it will be recalled that our observation window starts in 2000), we discard the outsourcing information from the 2000 and 2001 surveys and focus exclusively on the remaining three rounds. Also note that since establishments are required to report the change in outsourcing over the last two years, our sample is necessarily made up of all establishments in which we have information in both $t$ and $t-2$, with $t=2004,2007$, and 2010. We therefore have three separate panel samples, namely, 2002-2004, 2005-2007, and 2008-2010, each containing around 600,000 establishments (weighted data).

To avoid multiplication of the number of cases, and to keep the exercise as simple as possible, we (a) conflate the two active collective bargaining regimes into a single category (i.e. any type of collective agreement), and (b) consider two different subsamples made up of collective bargaining leavers and collective bargaining always members on the one hand, and collective bargaining joiners and collective bargaining never members 
Table 8. Collective bargaining regime and outsourcing, 2002-2004, 2005-2007, and 20082010 , in percentages.

Conditional probability of increasing outsourcing given the initial collective bargaining state

\begin{tabular}{lllll}
\hline Initial collective & Sample & $t_{0}: 2002$ & $t_{0}: 2005$ & $t_{0}: 2008$ \\
bargaining state & & $t_{1}: 2004$ & $t_{1}: 2007$ & $t_{1}: 2010$ \\
& & $(2002-2004$ panel $)$ & $(2005-2007$ panel $)$ & $(2008-2010$ panel) \\
Not covered by & CB joiners & 6 & 18 & 6 \\
any collective & CB never & 5 & 7 & 6 \\
agreement at $t_{0}$ & members & & & \\
Covered by & CB leavers & 11 & 9 & 10 \\
some collective & CB always & 7 & 10 & 6 \\
agreement at $t_{0}$ & members & & & \\
\hline
\end{tabular}

on the other. The main aim of this simple difference-in-differences exercise is to attempt a first-pass procedure allowing us to infer something about the relationship between changes in collective bargaining status and changes in outsourcing, the presumption being that, in principle, leavers (joiners) will tend to have a higher (lower) probability of increasing outsourcing than always members (never members).

The results of this exercise are given in Table 8 . There is some suggestion that outsourcing is more likely to be observed among those establishment that exit collective bargaining than among those that have remained 'covered' by any type of collective agreement. That said, there is no indication that joiners decrease their outsourcing activities to a greater degree than the comparison group of always members. In any event, observe that in two out of three cases, leavers do have a higher probability of increasing outsourcing than do joiners. But there is scant evidence in these data that outsourcing can be seen as the culprit for the pronounced decline in collective bargaining coverage.

\section{Concluding remarks}

We have sought to provide comprehensive information on the architecture of the German system of industrial relations in an essentially descriptive framework because we have argued that the extant information on changes in that system is fragmented. Providing consistent nationally representative data on the institutions of collective bargaining addresses the external erosion of the system by charting the decline in sectoral bargaining and the corresponding growth in the bargaining-free (or individual bargaining) zone. Widening the inquiry to consider somewhat neglected corresponding changes in the joint presence of works councils and sectoral bargaining coverage also addresses, however bluntly, the issue of the internal erosion of collective bargaining as well.

Our principal finding is that the decline in sectoral collective bargaining, first observed in the 1980s and 1990s, is ongoing. It is apparent for establishments that survive throughout the period and for those that die. Thus, the observed decline in collective bargaining is not driven by the composition of the sample. Failing plants are no more likely to be covered by a sectoral agreement at the point of failure than the generality of establishments - closing establishments are mostly from the no agreement sector. Uniquely, 
traditional bargaining coverage in new establishments evinces no trend over time but its level lies below that of continuing and failing establishments.

There are also marked regional differences in levels of coverage. The coverage of sectoral bargaining is much greater in western than in eastern Germany, and developments in the former region have necessarily dominated national trends even if declines have been roughly proportional in the two halves of Germany. That said, east German developments may have proved a catalyst in promoting greater decentralization in sectoral bargaining elsewhere in the system - a point echoed in Silvia's (2013: 225) depiction of reunification as providing an incubator for collective bargaining innovations.

There are also differences in the decline in traditional bargaining by establishment size and by sector. Large establishments ( $>250$ employees) have broadly double the coverage of sectoral bargaining than their counterparts with fewer employees. But declines again characterize both types, albeit at roughly half the rate in large plants as in small plants. As for manufacturing vs. services, again the predominant trend is downward. That said, certain sectors exhibit near stability of coverage and yet others only modest decline (e.g. construction and banking, respectively). Interestingly, those sectors with high bargaining coverage in western Germany - in ascending order, construction, energy/water/waste/mining, financial services, and public services/social insurance also evince high coverage in eastern Germany. Collective bargaining coverage by employment in these four sectors as of 2011 was $67 \%(50 \%), 71 \%(48 \%), 79 \%(51 \%)$, and $87 \%(83 \%)$, respectively - where the figures in parentheses are for eastern Germany (see Ellguth and Kohaut, 2012: 298).

We also detect some erosion in works council coverage, most obviously in terms of the share of establishments covered measure. Declining works council coverage was first noted by Hassel (1999), and it appears to be ongoing despite recent legislation - the 2001 Works Constitution Act - that sought to facilitate their formation (see Addison et al., 2004). More important still from the perspective of the distinctiveness and exclusivity of the German model is the declining share of establishments (and workers) having sectoral bargaining and works councils. Also of interest is the relatively high share of employees in establishments with sectoral agreements that are without works councils, amounting to two-fifths of employees. In short, the dual system still appears to be in retreat more than a decade after the deliberations of the Kommission Mitbestimmung (1998). But there is little to suggest that works council decline has exacerbated internal erosion.

We found no real evidence of any material increase in the extent of firm-level collective bargaining. Arguably, this source of decentralization has lost steam, most obviously in western Germany. One possibility is that contractual innovations - in particular, opening clauses and pacts for employment and competitiveness - have made firm-level agreements (if not collective bargaining free regimes) less attractive on transaction cost grounds. One form of flexibility may thus have been replaced by another. But this conjecture requires formal evaluation.

Identification of the causes of the erosion of traditional bargaining has proven elusive, although there is no shortage of informal explanations. These include globalization (uniform wages across a sector become less relevant with an increase in international product market competition), new and more differentiated forms of organizing work that require possibilities to vary remuneration at the level of the production unit, and structural changes (see Ochel, 2005: 99). We examined one such candidate - outsourcing - but 
found little support for the notion that increases in outsourcing have had implications for the shrinkage in area-wide bargaining, although more work is clearly required here.

If still in decline, what factors might be expected to curb the erosion of the dual system? The consensus seems to be that whatever the prospects for a strengthening in union organizational power (e.g. through increased organization of the service sector and newly emerging industries, and organizational reform such as 'Projekt IG Metall, 2009') any such development is unlikely to be sufficient in and of itself. Our own limited investigation has revealed scant evidence of revitalization from below. German writers thus tend to speak instead of a process of institutional stabilization through the polity (e.g. Bispinck and Schulten, 2009; Bispinck et al., 2010). This restabilization from above implies the enhanced use of extension provisions or their equivalents. Arguably, the first stage in this battle seems to have been won with the agreement of the new coalition government on a national minimum wage. (Industry-specific minimum wages for certain groups of workers were introduced in Germany under the 1996 Posted Workers Act/Arbeitnehmer-Entsendegesetz. Although initially restricted to the construction industry and kindred trades - e.g. roofing and electrical trades - some 12 sectors are now covered. They include waste disposal, commercial cleaning, industrial laundries, security services, nursing care services, postal services, and temporary help work agencies.) Statutory minimum wages can set a wage floor that some sectors might build upon to reintroduce collective bargaining. That said, the more practical instrument of institutional stabilization would be more extensive extension provisions, ${ }^{14}$ which have been shown in countries such as the Netherlands to have stabilized the collective bargaining system (see, for example Zachert, 2003, 2004; although for a more skeptical view, see Silvia, 2013: 226-228).

Absent these supports, the German model may be expected to continue its transformation toward a competition-driven model of wage regulation (Hassel and Rehder, 2001) in which traditional wage bargaining institutions if not their functions are preserved albeit for a changed subset made up of larger German employers. In this event, appearances would be deceptive.

\section{Funding}

John Addison gratefully acknowledges research support from the Riegel and Emory Human Resource Center of the University of South Carolina.

\section{Notes}

1. We comment on Hassel's (2014) most recent diagnosis in the next section.

2. However, a recent text by Silvia (2013) has done much to clarify the process of change behind which the German industrial relations system has ostensibly continued to perform much as intended. This English-language treatment goes behind the veil to provide a detailed picture of German industrial relations at the level of the actors on the one hand and the level of the law and the state on the other. Weaknesses are laid at the door of the social partners, since the law and the state have been supportive throughout. Membership losses of the union movement are attributed to 'a shift in the labor milieu,' a societal movement away from collectivism toward individualization. The employer associations' problems are allied to heightened market competition and emerging conflicts between their constituents. Their respective strategies for survival are also discussed in detail, against the backdrop of the continuing forces making for erosion. 
3. Under the agreement, working hours could differ for different groups of employees, working time accounts could be set up that permitted companies to deviate temporarily from the weekly agreed norm by compensating the worker with free time during a given period, and individual working time could vary within a certain corridor without triggering overtime bonuses.

4. Pforzheim basically allowed derogations to improve competitiveness, safeguard employment, and facilitate new investment. The agreement was in large part forced upon the unions by government (under Agenda 2010) which had threatened to change the legal framework of collective bargaining if there was no agreement between the parties on the 'opening up' of what were seen as inflexible area-wide industry agreements (see Gerhard Schröder: Regierungserklärung von Bundeskanzler Schröder vor dem Deutschen Bundestag (14 March 2003), at: archiv.bundesregierung.de/bpaexport/regierungserklaerung/79/472179/multi.htm.

5. Note that pacts are also used in establishments not covered by collective agreements.

6. Hassel argues that this reliance on a services sector characterized by cost cutting has been made possible by privatization policies and labor market reforms specifically aimed at (deregulation of) the peripheral labor market.

7. Separate 20-year perspectives on the contributions of industrial relations specialists and labor economists to the study of unions and collective bargaining are offered by Müller-Jentsch (2013) and Jirjahn (2013), respectively.

8. Deunionization and contractual innovation are in turn traced to the costs of German reunification and the opening up of nearby central and eastern European economies that offered a foretaste of the challenges of globalization.

9. Thus, taking contractual innovations as a case in point, of the 137 empirical inquiries identified in Jirhahn's (2013) wide-ranging overview, just 11 studies cover such practices.

10. Statistically significant trend increases were recorded in the sector with neither collective bargaining nor works councils, where coverage by establishment (employment) rose from $46.6 \%(27.2 \%)$ in 2000 to $62.5 \%$ (36.8\%) in 2011 .

11. One possible qualification to these findings on worker representation has to do with forms of employee involvement other than in works councils. The evidence suggests that the share of establishments and employment in plants practicing these other forms of involvement has risen at the same time as the corresponding shares of establishments with works councils has fallen (see Ellguth and Kohaut, 2011: 246; 2013: 286). At issue is whether employee involvement and analogous workplace practices are complementary or substitutes for works councils (see Addison et al., 2007; Ellguth, 2005).

12. See Addison et al. (2013) for a full discussion of whether the change in collective bargaining coverage is due to changes in establishment (observed) characteristics or to changes in establishment propensity to be covered by a collective agreement over approximately the same interval. The latter effect (or the within effect) is overwhelming dominant as an explanation for the observed decline in collective bargaining.

13. The above patterns generally carry over to the population of permanent stayers (results for whom are available upon request). Perhaps the most obvious contrast with the results in Table 5 is that the 'always existing' category is persistently higher for sectoral agreements among permanent stayers. This might be expected given that permanent stayers are on average of bigger size than the average establishment in the population.

14. The extension of collective agreements to all companies within a specific sector is provided for under section 5 of the Tarifvertragsgestetz. This legislation allows for an extension of collective agreements to all firms within a sector where the existing agreement covers one-half of the employees and where that extension is adjudged to be in the public interest. A majority of the tripartite collective bargaining committee in the Ministry of Labor has to approve the extension. As of 2009 , just $1.5 \%$ of sectoral agreements were subject to extension. 


\section{References}

Addison JT (2009) The Economics of Codetermination. New York: Palgrave Macmillan.

Addison JT, Bellmann L, Schnabel C and Wagner J (2004) The reform of the German Works Constitution Act: A critical appraisal. Industrial Relations 43(2): 392-420.

Addison JT, Schnabel C and Wagner J (2007) The (parlous) state of German unions. Journal of Labor Research 28(1): 3-18.

Addison JT, Teixeira P and Zwick T (2010) German works councils and the anatomy of wages. Industrial and Labor Relations Review 63(2): 248-271.

Addison JT, Bryson A, Teixeira P and Pahnke A (2011) Slip sliding away: Further union decline in Germany and Britain. Scottish Journal of Political Economy 58(4): 490-518.

Addison JT, Teixeira P, Bryson A and Pahnke A (2013) Collective agreement status and survivability: Change and persistence in the German model. Labour 27(3): 288-309.

Addison JT, Kölling A and Teixeira P (2014) Changes in bargaining status and intra-plant wage dispersion in Germany: A case of (almost) plus ça change? IZA Discussion Paper No. 8359, July. Bonn: Institute for the Study of Labor.

Artus I (2008) Interessenhandeln jenseits der Norm. Mittelständische Betriebe und prekäre Dienstleistungsarbeit in Deutschland und Frankreich. Frankfurt am Main and New York: Campus Verlag.

Bellmann L and Gerner H-D (2012a) Continuous training and company-level pacts for employment in Germany. Jahrbücher fur Nationalökonomie und Statistik 232(2): 98-115.

Bellmann L and Gerner H-D (2012b) Company-level pacts for employment in the global crisis 2008/2009: First evidence from representative German establishment data. International Journal of Human Resource Management 23(6): 3375-3396.

Bellmann L, Gerlach K and Meyer W (2008) Company-level pacts for employment. Jahrbücher fur Nationalökonomie und Statistik 228(5/6): 533-553.

Bellman L, Gerner H-D and Hübler O (2014) Investment under company level pacts before and during the Great Recession. Economic and Industrial Democracy (forthcoming).

Bispinck R and Schulten T (2009) Re-stabilisierung des deutschen Flächentarifvertragssystems. WSI-Mitteilungen 62(4): 201-209.

Bispinck R and Schulten T (2010) Sector-level bargaining and the possibilities for deviations at company level: The case of Germany. In: The Functioning of Wage Bargaining Systems and Wage Setting Mechanisms in Adverse Labor Market Conditions, Eurofound project. Dublin: European Foundation for the Improvement of Living and Working Conditions.

Bispinck R, Dribbusch H and Schulten T (2010) German collective bargaining in a European perspective. Continuous erosion or re-stabilisation of multi-employer agreements? WSI Discussion Paper No. 171. Düsseldorf: Wirtschafts- und Sozialwissenschaftliches Institut, Hans-Böckler-Stiftung.

Bosch G and Weinkopf C (eds) (2008) Low Wage Work in Germany. New York: Russell Sage Foundation.

Brändle T (2013) Flexible collective bargaining agreements: Still a moderating effect on works council behavior? Unpublished paper, Institute for Applied Economic Research/IAW, University of Tübingen.

Brändle T and Heinbach W-D (2013) Opening clauses in collective bargaining agreements: More flexibility to save jobs. Jahrbuch für Wirtschaftswissenschaften/Review of Economics 64(2): 159-192.

Doellgast V and Greer I (2007) Vertical disintegration and the disorganization of German industrial relations. British Journal of Industrial Relations 45(1): 55-76.

Dustmann C, Ludsteck J and Schönberg U (2009) Revisiting the German wage structure. Quarterly Journal of Economics 124(2): 843-881. 
Dustmann C, Fitzenberger B, Schönberg U and Spitz-Oener A (2014) From sick man of Europe to economic superstar: Germany's resurgent economy. Journal of Economic Perspectives 28(1): $167-188$.

Ellguth P (2005) Betriebe ohne Betriebsrat - welche Rolle Spielen betriebsspezifische Formen der Mitarbeitervertretung? Industrielle Beziehungen 12(2): 149-176.

Ellguth P and Kohaut S (2008) Ein Bund fürs Überleben? Betriebliche Vereinbarungen zur Beschäftigungs- und Standortsicherung. Industrielle Beziehungen 15(3): 209-232.

Ellguth P and Kohaut S (2010) Aus der Flucht? Tarifaustritte und die Rolle von Öffnungsklauseln. Industrielle Beziehungen 17(4): 345-371.

Ellguth P and Kohaut S (2011) Tarifbindung und betriebliche Interessenvertretung: Aktuelle Ergebnisse aus dem IAB-Betriebspanel 2010. WSI-Mitteilungen 64(5): 242-247.

Ellguth P and Kohaut S (2012) Tarifbindung und betriebliche Interessenvertretung: Aktuelle Ergebnisse aus dem IAB-Betriebspanel 2011. WSI-Mitteilungen 65(4): 297-305.

Ellguth P and Kohaut S (2013) Tarifbindung und betriebliche Interessenvertretung: Ergebnisse aus dem IAB-Betriebspanel 2012. WSI-Mitteilungen 66(4): 281-288.

Ellguth P, Gerner H-D and Stegmaier J (2014) Wage effects of works councils and opening clauses: The German case. Economic and Industrial Democracy 35(1): 95-113.

Fischer G, Janik F, Müller D and Schmucker A (2009) The IAB Establishment Panel: Things users should know. Schmollers Jahrbuch 129(1): 133-148.

Garloff A and Gürtzgen N (2012) Collective wage contracts, opt-out clauses and firm wage-differentials: Evidence from linked employer employee data. Industrial Relations 51(3): 731-748.

Gürtzgen N (2010) Rent-sharing and collective wage contracts: Evidence from German establishment-level data. Applied Economics 42(22): 2385-2854.

Haipeter T (2011a) 'Unbound' employers' associations and derogations: Erosion and renewal of collective bargaining in the German metalworking industry. Industrial Relations Journal 42(2): 174-194.

Haipeter T (2011b) Works councils as actors of collective bargaining: Derogations and the development of codetermination in the German chemical and metalworking industries. Economic and Industrial Democracy 32(4): 679-695.

Haipeter T (2013) Erosion, exhaustion or renewal? New forms of collective bargaining in Germany. In: Stone KVW and Arthurs H (eds) Rethinking Workplace Regulation: Beyond the Standard Contract of Employment. New York: Russell Sage Foundation, pp. 115-134.

Haipeter T and Lehndorff S (2009) Collective bargaining on employment. Working Paper No. 3, Industrial Relations Department. Geneva: International Labour Office.

Hassel A (1999) The erosion of the German system of industrial relations. British Journal of Industrial Relations 37(3): 483-505.

Hassel A (2002) The erosion continues: Reply [to Klikauer]. British Journal of Industrial Relations 40(2): 309-317.

Hassel A (2014) The paradox of liberalization: Understanding dualism and the recovery of the German political economy. British Journal of Industrial Relations 52(1): 57-81.

Hassel A and Rehder B (2001) Institutional change in the German wage bargaining system: The role of big companies. MPIfg Working Paper 01/01/9. Köln: Max Planck Institute for the Study of Societies/Max-Planck-Institut für Gesellschaftsforschung.

Heinbach W-D and Schröpfer S (2007) Typisierung der Tarifvertragslandschaft - Eine Clusteranalyse der tarifvertraglichen Öffnungsklauseln. Journal of Economics and Statistics 227(3): 219-235.

Heinbach W-D and Schröpfer S (2008) What a difference trade makes: Export activity and the flexibility of collective bargaining agreements. Journal of Labor Market Research 41(2/3): 287-303. 
Hethey-Maier T and Schmieder JF (2010) Using worker flows in the analysis of establishment turnover: Evidence from German administrative data. FDZ-Methodenreport 06/2010. Nürnberg: Research Data Centre (FDZ), Institute for Employment Research, Federal German Labor Agency.

Hethey-Maier T and Seth S (2010) Das Betriebs-Historik-Panel (BHP) 1975-2008. Handbuch Version 1.0.2. FDZ-Datenreport 04/2010. Nürnberg: Research Data Centre (FDZ), Institute for Employment Research, Federal German Labor Agency.

Holst H, Nachtwey O and Dörre K (2010) The strategic use of temporary agency work: Functional change of a non-standard form of employment. International Journal of Action Research 6: $108-138$.

Hübler O (2005a) Sind betriebliche Bündnisse für Arbeit erfolgreich? Jahrbücher für Nationalökonomie und Statistik 225(6): 630-652

Hübler O (2005b) Betriebliche Vereinbarungen zur Beschäftigungs- und Standortsicherung. In: Bellmann L, Hübler O, Meyer W and Stephan G (eds) Institutionen, Löhne, und Beschäftigung. Beiträge zur Arbeitsmarkt- und Berufsforschung, 294. Nürnberg: Institute for Employment Research, Federal German Labor Agency, pp. 157-173.

Hübler O (2006) Zum Einfluss betrieblicher Bündnisse auf die wirtschaftliche Lage der Unternehmen. Jahrbuch für Wirtschaftswissenschaften/Review of Economics 57(2): 121-146.

Hübler O and Jirjahn U (2003) Works councils, and collective bargaining in Germany: The impact on productivity and wages. Scottish Journal of Political Economy 50(4): 471-491.

Jirjahn U (2013) Der Beitrag der Arbeitsmarktökonomik zur Erforschung von Gewerkschaften und Tarifvertragsbeziehungen in Deutschland. Industrielle Beziehungen 20(4): 367-392.

Kommission Mitbestimmung (1998) Mitbestimmung und neue Unternehmenskulturen - Bilanz und Perspektiven. Gütersloh: Verlag Bertelsmann Stiftung.

Massa-Wirth H and Niechoj T (2004) Supranational Coordination but National Fragmentation: Interplay of European Economic Policy and Firm-level Pacts in Germany. Düsseldorf: Das Wirtschafts- und Sozialwissenschaftliche Institut (WSI) der Hans-Böckler-Stiftung. Available at: poloek-dvpw.mpifg.de/e_documents/publikationen/Massa-wirth $\% 20$ Niechoj\%20-\%20 Supranational\%20Coordination.pdf.

Müller-Jentsch W (1995) Germany: From collective voice to co-management. In: Rogers J and Streeck W (eds) Works Councils, Consultation, Representation and Cooperation in Industrial Relations. Chicago: Chicago University Press, pp. 53-78.

Müller-Jentsch W (2013) Zwanzig Jahre Industrielle Beziehungen - Rückblick und Bilanz. Industrielle Beziehungen 20(4): 258-284.

Ochel W (2005) Decentralizing wage bargaining in Germany: A way to increase employment? Labour 19(1): 91-121.

Schnabel C, Zagelmeyer S and Kohaut S (2006) Collective bargaining structure and its determinants: An empirical analysis with British and German establishment data. European Journal of Industrial Relations 12(2): 165-188.

Seifert H and Massa-Wirth H (2005) Pacts for employment and competitiveness in Germany. Industrial Relations Journal 36(3): 217-240.

Silvia SJ (2013) Holding the Shop Together: German Industrial Relations in the Postwar Era. Ithaca, NY and London: ILR Press.

Silvia SJ and Schroeder W (2007) Why are German employers' associations declining? Arguments and evidence. Comparative Political Studies 40(12): 1433-1459.

Streeck W (2010) Re-forming Capitalism: Institutional Change in the German Political Economy. Oxford and New York: Oxford University Press.

Thelen K (1991) Union of Parts: Labor Politics in Postwar Germany. Ithaca, NY: Cornell University Press. 
Zachert U (2003) Reformperspektiven der Allgemeinverbindlicherklärung aus arbeitsrechtlicher Sicht. WSI-Mitteilungen 56(7): 413-419.

Zachert U (2004) Allgemeinverbindlicherklärung. In: Peter G, Kempen OE and Zachert U (eds) Die Sicherung tariflicher Mindeststandards. Baden-Baden: Hans-Böckler-Stiftung, pp. 11-32.

\section{Author biographies}

John T Addison is Professor of Economics at the University of South Carolina, USA and Chair in Economics at Durham University Business School, UK. He has published widely in the major economics and specialty labor journals, and is among the top 30 labor economists in the current $\mathrm{RePEc}$ rankings for this field. His most recent book is The Economics of Codetermination: Lessons from the German Experience (2009). His research interests include minimum wages, high dimensional fixed effect wage regression models, and female promotion and pay.

Paulino Teixeira is Professor of Economics at the University of Coimbra and Research Fellow at IZA, Bonn. He is also a member of the Evaluation Panel of the Portuguese Foundation for Science and Technology. Teixeira has published in a wide range of economics and labor economics journals including Industrial and Labor Relations Review, Industrial Relations, and the Journal of Productivity Analysis. His current research interests focus on the analysis of unions and wage determination.

André Pahnke is a researcher with the Institut für Mittelstandsforschung located in Bonn, Germany. His work has been published in such journals as the Manchester School and the Scottish Journal of Political Economy. His research fields cover labor economics, industrial relations, finance, and the economics of small and medium-sized enterprises.

Lutz Bellmann is Professor of Labor Economics at the University of Erlangen-Nuremberg and head of the department Establishments and Employment at the Institute for Employment Research in Nuremberg. His main research interests are industrial relations, firm-level employment adjustments and firm-provided training, with recent publications in the Review of World Economics, International Journal of Manpower, and the Jahrbücher für Nationalökonomie und Statistik. 


\section{Appendix}

Table AI. Collective bargaining and works council coverage for Germany and by broad region, 2000-20I I, all establishments, weighted data, in percentages.

\begin{tabular}{|c|c|c|c|c|c|c|c|c|c|}
\hline \multirow[b]{3}{*}{ Year } & \multirow[b]{3}{*}{ Region } & \multicolumn{8}{|c|}{ Collective agreement status } \\
\hline & & \multicolumn{2}{|c|}{$\begin{array}{l}\text { Sectoral } \\
\text { agreement }\end{array}$} & \multicolumn{2}{|c|}{$\begin{array}{l}\text { Firm-level } \\
\text { agreement }\end{array}$} & \multicolumn{2}{|c|}{ No agreement } & \multicolumn{2}{|c|}{$\begin{array}{l}\text { Works } \\
\text { council }\end{array}$} \\
\hline & & I & II & I & II & I & II & 1 & II \\
\hline \multirow[t]{3}{*}{2000} & Germany & 47.9 & 59.1 & 3.1 & 7.2 & 49.0 & 33.7 & 11.4 & 47.6 \\
\hline & West & 52.7 & 62.7 & 2.6 & 6.5 & 44.7 & 30.8 & 11.5 & 49.3 \\
\hline & East & 28.1 & 41.2 & 5.1 & 10.8 & 66.8 & 48.0 & 11.0 & 39.2 \\
\hline \multirow[t]{3}{*}{2001} & Germany & 46.5 & 59.5 & 2.7 & 7.5 & 50.8 & 33.0 & 11.2 & 48.7 \\
\hline & West & 51.2 & 63.5 & 2.2 & 6.3 & 46.6 & 30.1 & 11.4 & 50.4 \\
\hline & East & 27.2 & 39.8 & 4.7 & 13.2 & 68.2 & 47.0 & 10.5 & 40.5 \\
\hline \multirow[t]{3}{*}{2002} & Germany & 45.3 & 58.9 & 2.4 & 6.9 & 52.2 & 34.2 & 10.6 & 48.6 \\
\hline & West & 50.1 & 62.7 & 2.0 & 5.9 & 47.9 & 31.3 & 10.8 & 49.9 \\
\hline & East & 24.5 & 39.2 & 4.3 & 11.9 & 71.2 & 48.9 & 9.5 & 41.7 \\
\hline \multirow[t]{3}{*}{2003} & Germany & 44.8 & 58.2 & 2.2 & 7.2 & 53.0 & 34.7 & 10.3 & 47.3 \\
\hline & West & 49.9 & 61.9 & 1.8 & 6.5 & 48.2 & 31.6 & 10.5 & 48.7 \\
\hline & East & 23.1 & 39.2 & 3.6 & 10.7 & 73.2 & 50.1 & 9.3 & 40.1 \\
\hline \multirow[t]{3}{*}{2004} & Germany & 41.6 & 56.7 & 2.3 & 7.1 & 56.1 & 36.1 & 9.8 & 46.8 \\
\hline & West & 45.9 & 60.4 & 2.0 & 6.6 & 52.1 & 33.1 & 10.0 & 48.2 \\
\hline & East & 23.5 & 38.1 & 3.5 & 10.1 & 73.0 & 51.8 & 9.2 & 39.7 \\
\hline \multirow[t]{3}{*}{2005} & Germany & 40.5 & 55.2 & 2.4 & 7.3 & 57.1 & 37.5 & 10.2 & 46.2 \\
\hline & West & 44.3 & 58.5 & 2.0 & 6.8 & 53.7 & 34.7 & 10.6 & 47.7 \\
\hline & East & 24.4 & 37.8 & 4.1 & 10.4 & 71.5 & 51.9 & 9.1 & 38.0 \\
\hline \multirow[t]{3}{*}{2006} & Germany & 38.4 & 52.9 & 2.1 & 7.4 & 59.5 & 39.8 & 9.7 & 45.1 \\
\hline & West & 41.8 & 56.0 & 1.7 & 6.6 & 56.5 & 37.4 & 9.7 & 46.5 \\
\hline & East & 23.5 & 36.4 & 4.1 & 11.3 & 72.4 & 52.3 & 9.3 & 37.6 \\
\hline \multirow[t]{3}{*}{2007} & Germany & 37.1 & 52.0 & 2.3 & 7.0 & 60.6 & 40.9 & 9.5 & 44.6 \\
\hline & West & 40.6 & 55.1 & 1.8 & 6.3 & 57.6 & 38.5 & 9.6 & 46.2 \\
\hline & East & 22.0 & 35.4 & 4.3 & 10.8 & 73.6 & 53.8 & 8.7 & 35.7 \\
\hline \multirow[t]{3}{*}{2008} & Germany & 36.2 & 50.1 & 2.4 & 7.5 & 61.4 & 42.4 & 9.1 & 44.0 \\
\hline & West & 39.3 & 53.1 & 2.0 & 6.8 & 58.7 & 40.0 & 9.3 & 45.7 \\
\hline & East & 23.4 & 34.8 & 3.9 & 10.9 & 72.7 & 54.4 & 8.0 & 35.5 \\
\hline \multirow[t]{3}{*}{2009} & Germany & 36.0 & 49.7 & 2.6 & 8.3 & 61.3 & 42.0 & 9.2 & 44.7 \\
\hline & West & 39.6 & 52.8 & 2.3 & 7.7 & 58.1 & 39.5 & 9.3 & 46.4 \\
\hline & East & 21.1 & 33.9 & 4.0 & 11.5 & 74.9 & 54.6 & 9.1 & 36.2 \\
\hline \multirow[t]{3}{*}{2010} & Germany & 34.3 & 49.6 & 2.5 & 7.5 & 63.2 & 42.9 & 9.6 & 44.1 \\
\hline & West & 37.8 & 52.8 & 2.2 & 6.8 & 60.1 & 40.4 & 9.8 & 45.7 \\
\hline & East & 19.9 & 32.9 & 3.6 & 11.2 & 76.5 & 55.9 & 8.7 & 36.0 \\
\hline
\end{tabular}


Table AI. (Continued)

\begin{tabular}{|c|c|c|c|c|c|c|c|c|c|}
\hline \multirow[b]{3}{*}{ Year } & \multirow[b]{3}{*}{ Region } & \multicolumn{8}{|c|}{ Collective agreement status } \\
\hline & & \multicolumn{2}{|c|}{$\begin{array}{l}\text { Sectoral } \\
\text { agreement }\end{array}$} & \multicolumn{2}{|c|}{$\begin{array}{l}\text { Firm-level } \\
\text { agreement }\end{array}$} & \multicolumn{2}{|c|}{ No agreement } & \multicolumn{2}{|c|}{$\begin{array}{l}\text { Works } \\
\text { council }\end{array}$} \\
\hline & & 1 & II & I & II & 1 & II & I & II \\
\hline \multirow[t]{3}{*}{2011} & Germany & 32.9 & 47.8 & 2.4 & 7.2 & 64.6 & 45.0 & 9.3 & 42.4 \\
\hline & West & 36.1 & 51.0 & 2.1 & 6.4 & 61.8 & 42.6 & 9.4 & 44.0 \\
\hline & East & 19.8 & 32.1 & 3.9 & 11.0 & 76.3 & 56.9 & 8.7 & 34.5 \\
\hline \multirow[t]{3}{*}{ Trend } & Germany & $-* * *$ & $-* * *$ & n.s. & n.s. & $+* * *$ & $+* * *$ & -*** & -**** \\
\hline & West & $-* * *$ & $-* * *$ & n.s. & n.s. & $+* * *$ & $+* * *$ & _*** & _**** \\
\hline & East & -*** & $-* * *$ & n.s. & n.s. & $+* * *$ & $+* * *$ & -*** & _**** \\
\hline
\end{tabular}

Notes: I denotes the proportion of establishments and II the proportion of employees.

***, **, and * denote statistical significance at the $.01, .05$, and .10 levels, respectively.

Table A2. Collective bargaining and works council coverage for Germany and by broad region, 2000-20I I, permanent stayers, weighted data, in percentages.

\begin{tabular}{|c|c|c|c|c|c|c|c|c|c|}
\hline \multirow[b]{3}{*}{ Year } & \multirow[b]{3}{*}{ Region } & \multicolumn{8}{|c|}{ Collective agreement status } \\
\hline & & \multicolumn{2}{|c|}{$\begin{array}{l}\text { Sectoral } \\
\text { agreement }\end{array}$} & \multicolumn{2}{|c|}{$\begin{array}{l}\text { Firm-level } \\
\text { agreement }\end{array}$} & \multicolumn{2}{|c|}{ No agreement } & \multicolumn{2}{|c|}{ Works council } \\
\hline & & I & II & I & II & I & II & I & II \\
\hline \multirow[t]{3}{*}{2000} & Germany & 48.2 & 60.0 & 5.0 & 6.9 & 46.8 & 33.1 & 10.1 & 42.2 \\
\hline & West & 55.7 & 66.2 & 4.7 & 5.6 & 39.5 & 28.1 & 8.7 & 42.8 \\
\hline & East & 25.1 & 38.8 & 5.8 & 11.3 & 69.1 & 49.9 & 14.2 & 40.1 \\
\hline \multirow[t]{3}{*}{2001} & Germany & 51.2 & 60.6 & 4.4 & 7.5 & 44.4 & 31.9 & 11.7 & 45.1 \\
\hline & West & 59.1 & 66.4 & 3.7 & 5.9 & 37.2 & 27.7 & II.I & 46.3 \\
\hline & East & 26.4 & 38.5 & 6.6 & 13.7 & 67.0 & 47.8 & 13.8 & 40.6 \\
\hline \multirow[t]{3}{*}{2002} & Germany & 48.8 & 58.9 & 3.2 & 7.9 & 48.0 & 33.2 & 10.7 & 43.4 \\
\hline & West & 58.0 & 65.5 & 2.3 & 6.0 & 39.7 & 28.5 & 11.3 & 45.3 \\
\hline & East & 24.2 & 37.3 & 5.7 & 14.0 & 70.1 & 48.7 & 8.9 & 36.9 \\
\hline \multirow[t]{3}{*}{2003} & Germany & 52.7 & 60.6 & 1.6 & 8.6 & 45.7 & 30.8 & 11.3 & 47.1 \\
\hline & West & 62.1 & 66.0 & I.I & 8.0 & 36.8 & 25.9 & 12.2 & 49.5 \\
\hline & East & 23.7 & 40.5 & 3.1 & 10.8 & 73.2 & 48.8 & 8.4 & 38.5 \\
\hline \multirow[t]{3}{*}{2004} & Germany & 50.0 & 58.8 & 1.7 & 8.2 & 48.3 & 33.0 & 10.8 & 45.8 \\
\hline & West & 59.2 & 64.7 & I.I & 7.3 & 39.7 & 27.9 & 11.3 & 47.8 \\
\hline & East & 23.9 & 37.5 & 3.4 & 11.3 & 72.7 & 51.1 & 9.3 & 38.9 \\
\hline \multirow[t]{3}{*}{2005} & Germany & 48.3 & 57.7 & 1.8 & 7.1 & 49.9 & 35.2 & 10.4 & 44.3 \\
\hline & West & 55.5 & 62.4 & 1.3 & 6.1 & 43.2 & 31.5 & 10.8 & 45.5 \\
\hline & East & 26.2 & 40.6 & 3.5 & 10.6 & 70.3 & 48.8 & 9.4 & 39.8 \\
\hline 2006 & Germany & 45.8 & 55.9 & 2.3 & 8.4 & 51.9 & 35.7 & 12.1 & 46.2 \\
\hline
\end{tabular}


Table A2. (Continued)

\begin{tabular}{|c|c|c|c|c|c|c|c|c|c|}
\hline \multirow[b]{3}{*}{ Year } & \multirow[b]{3}{*}{ Region } & \multicolumn{8}{|c|}{ Collective agreement status } \\
\hline & & \multicolumn{2}{|c|}{$\begin{array}{l}\text { Sectoral } \\
\text { agreement }\end{array}$} & \multicolumn{2}{|c|}{$\begin{array}{l}\text { Firm-level } \\
\text { agreement }\end{array}$} & \multicolumn{2}{|c|}{ No agreement } & \multicolumn{2}{|c|}{ Works council } \\
\hline & & $\mathrm{I}$ & II & 1 & II & 1 & II & 1 & II \\
\hline & West & 52.9 & 60.6 & 1.5 & 7.6 & 45.6 & 31.8 & 12.4 & 47.9 \\
\hline & East & 24.1 & 37.7 & 4.8 & 11.6 & 71.1 & 50.7 & II.I & 40.0 \\
\hline \multirow[t]{3}{*}{2007} & Germany & 44.5 & 54.2 & 2.3 & 8.6 & 53.2 & 37.2 & 11.6 & 48.3 \\
\hline & West & 51.1 & 58.2 & 1.3 & 8.0 & 47.6 & 33.9 & 11.9 & 50.3 \\
\hline & East & 23.4 & 37.5 & 5.3 & 11.3 & 71.3 & 51.2 & 10.6 & 39.9 \\
\hline \multirow[t]{3}{*}{2008} & Germany & 43.0 & 54.0 & 2.2 & 8.4 & 54.9 & 37.6 & 11.6 & 49.7 \\
\hline & West & 48.8 & 57.9 & 1.3 & 7.1 & 49.9 & 35.0 & 12.3 & 52.0 \\
\hline & East & 26.3 & 39.6 & 4.5 & 13.4 & 69.2 & 47.0 & 9.6 & 41.4 \\
\hline \multirow[t]{3}{*}{2009} & Germany & 42.9 & 54.5 & 2.1 & 9.6 & 55.0 & 35.9 & 11.5 & 51.0 \\
\hline & West & 49.7 & 59.0 & 1.5 & 8.8 & 48.9 & 32.2 & 12.2 & 53.6 \\
\hline & East & 23.3 & 37.5 & 3.8 & 12.7 & 72.9 & 49.9 & 9.7 & 41.2 \\
\hline \multirow[t]{3}{*}{2010} & Germany & 41.4 & 55.1 & 2.4 & 9.5 & 56.3 & 35.3 & 12.6 & 53.9 \\
\hline & West & 47.6 & 59.6 & 1.7 & 8.3 & 50.7 & 32.1 & 13.4 & 56.0 \\
\hline & East & 23.5 & 37.5 & 4.3 & 14.3 & 72.2 & 48.2 & 10.4 & 45.6 \\
\hline \multirow[t]{3}{*}{2011} & Germany & 40.2 & 54.0 & 2.8 & 8.6 & 57.1 & 37.4 & 11.8 & 49.9 \\
\hline & West & 46.3 & 58.4 & 2.2 & 7.2 & 51.6 & 34.4 & 12.6 & 51.6 \\
\hline & East & 22.6 & 38.0 & 4.5 & 13.6 & 72.9 & 48.4 & 9.5 & 43.9 \\
\hline \multirow[t]{3}{*}{ Trend } & Germany & _*** & _*** & $-*$ & $+* * *$ & $+* * *$ & $+* * *$ & $+* *$ & $+* * *$ \\
\hline & West & _*** & _*** & -* & $+* *$ & $+* * *$ & $+* * *$ & $+* * *$ & $+* * *$ \\
\hline & East & n.s. & n.s. & n.s. & n.s. & $+*$ & n.s. & n.s. & $+* * *$ \\
\hline
\end{tabular}

Notes: I denotes the proportion of establishments and II the proportion of employees. $* * *, * *$, and $*$ denote statistical significance at the $.01, .05$, and .10 levels, respectively. 
Table A3. Collective bargaining and works council coverage for Germany and by broad region, 2000-2010, newly-founded establishments, weighted data, in percentages.

\begin{tabular}{|c|c|c|c|c|c|c|c|c|c|}
\hline \multirow[b]{3}{*}{ Year } & \multirow[b]{3}{*}{ Region } & \multicolumn{8}{|c|}{ Collective agreement status } \\
\hline & & \multicolumn{2}{|c|}{$\begin{array}{l}\text { Sectoral } \\
\text { agreement }\end{array}$} & \multicolumn{2}{|c|}{$\begin{array}{l}\text { Firm-level } \\
\text { agreement }\end{array}$} & \multicolumn{2}{|c|}{ No agreement } & \multicolumn{2}{|c|}{$\begin{array}{l}\text { Works } \\
\text { council }\end{array}$} \\
\hline & & I & II & I & II & 1 & II & I & II \\
\hline \multirow[t]{3}{*}{2000} & Germany & 33.8 & 39.0 & 2.2 & 5.5 & 64.0 & 55.5 & 7.1 & 34.0 \\
\hline & West & 38.9 & 40.9 & 2.1 & 6.1 & 59.0 & 53.0 & 5.9 & 35.3 \\
\hline & East & 16.5 & 32.3 & 2.7 & 3.2 & 80.7 & 64.5 & 11.0 & 29.2 \\
\hline \multirow[t]{3}{*}{2001} & Germany & 30.3 & 41.7 & 2.4 & 8.1 & 67.4 & 50.2 & 7.7 & 32.6 \\
\hline & West & 33.7 & 45.5 & 2.6 & 8.1 & 63.7 & 46.4 & 6.9 & 33.9 \\
\hline & East & 15.3 & 22.2 & 1.5 & 8.2 & 83.2 & 69.6 & 11.2 & 25.8 \\
\hline \multirow[t]{3}{*}{2002} & Germany & 32.3 & 47.3 & 2.7 & 5.0 & 65.1 & 47.7 & 8.5 & 35.3 \\
\hline & West & 35.3 & 51.5 & 2.5 & 4.2 & 62.3 & 44.2 & 8.6 & 36.4 \\
\hline & East & 16.3 & 25.2 & 3.6 & 9.2 & 80.1 & 65.6 & 7.9 & 29.3 \\
\hline \multirow[t]{3}{*}{2003} & Germany & 32.5 & 43.8 & 3.9 & 6.3 & 63.6 & 49.9 & 10.0 & 35.6 \\
\hline & West & 36.7 & 48.7 & 4.3 & 5.8 & 59.1 & 45.5 & 10.2 & 37.7 \\
\hline & East & 15.9 & 22.0 & 2.2 & 8.5 & 81.8 & 69.5 & 9.1 & 26.3 \\
\hline \multirow[t]{3}{*}{2004} & Germany & 28.0 & 40.9 & 2.9 & 8.1 & 69.1 & 51.0 & 7.3 & 35.0 \\
\hline & West & 30.8 & 44.3 & 2.9 & 8.2 & 66.3 & 47.5 & 7.0 & 36.3 \\
\hline & East & 17.3 & 27.2 & 3.2 & 7.4 & 79.6 & 65.4 & 8.4 & 29.7 \\
\hline \multirow[t]{3}{*}{2005} & Germany & 32.1 & 43.1 & 2.4 & 7.5 & 65.5 & 49.4 & 7.4 & 31.5 \\
\hline & West & 35.2 & 46.6 & 1.9 & 6.9 & 62.9 & 46.5 & 7.5 & 33.0 \\
\hline & East & 19.3 & 28.2 & 4.1 & 10.2 & 76.5 & 61.7 & 6.7 & 24.8 \\
\hline \multirow[t]{3}{*}{2006} & Germany & 31.9 & 41.4 & 2.2 & 6.4 & 65.8 & 52.1 & 6.7 & 30.4 \\
\hline & West & 34.8 & 44.5 & 1.7 & 5.6 & 63.5 & 49.9 & 6.8 & 31.7 \\
\hline & East & 20.2 & 28.5 & 4.2 & 10.0 & 75.6 & 61.5 & 6.3 & 24.7 \\
\hline \multirow[t]{3}{*}{2007} & Germany & 30.3 & 40.4 & 2.5 & 5.9 & 67.3 & 53.7 & 5.8 & 27.5 \\
\hline & West & 32.6 & 42.6 & 2.3 & 4.8 & 65.1 & 52.5 & 5.8 & 28.6 \\
\hline & East & 20.6 & 30.6 & 3.1 & 10.3 & 76.3 & 59.1 & 6.0 & 23.1 \\
\hline \multirow[t]{3}{*}{2008} & Germany & 30.1 & 41.0 & 2.6 & 6.1 & 67.3 & 53.0 & 6.6 & 28.4 \\
\hline & West & 32.0 & 43.2 & 2.4 & 5.2 & 65.6 & 51.6 & 6.7 & 29.5 \\
\hline & East & 22.8 & 31.7 & 3.4 & 9.7 & 73.9 & 58.6 & 6.3 & 23.7 \\
\hline \multirow[t]{3}{*}{2009} & Germany & 30.1 & 39.3 & 2.6 & 7.9 & 67.3 & 52.8 & 6.4 & 28.4 \\
\hline & West & 32.2 & 41.5 & 2.3 & 7.2 & 65.5 & 51.3 & 6.3 & 29.2 \\
\hline & East & 21.4 & 30.3 & 3.8 & 10.9 & 74.7 & 58.8 & 7.1 & 25.0 \\
\hline \multirow[t]{3}{*}{2010} & Germany & 29.2 & 39.4 & 2.6 & 6.8 & 68.2 & 53.9 & 7.1 & 27.5 \\
\hline & West & 31.5 & 41.9 & 2.3 & 5.8 & 66.1 & 52.3 & 7.2 & 27.9 \\
\hline & East & 19.7 & 28.9 & 3.5 & 10.7 & 76.8 & 60.3 & 7.0 & 26.0 \\
\hline \multirow[t]{3}{*}{ Trend } & Germany & -* & n.s. & n.s. & n.s. & $+*$ & n.s. & -* & _*** \\
\hline & West & $-* *$ & n.s. & n.s. & n.s. & $+* *$ & n.s. & n.s. & _*** \\
\hline & East & $+* * *$ & n.s. & $+*$ & $+* * *$ & $\_* * *$ & - **** & - **** & _** \\
\hline
\end{tabular}

Notes: I denotes the proportion of establishments and II the proportion of employees.

***, **, and * denote statistical significance at the $.01, .05$, and .10 levels, respectively. 
Table A4. Collective bargaining and works council coverage for Germany and by broad region, 2000-2009, closing establishments, weighted data, in percentages.

\begin{tabular}{|c|c|c|c|c|c|c|c|c|c|}
\hline \multirow[b]{3}{*}{ Year } & \multirow[b]{3}{*}{ Region } & \multicolumn{8}{|c|}{ Collective agreement status } \\
\hline & & \multicolumn{2}{|c|}{$\begin{array}{l}\text { Sectoral } \\
\text { agreement }\end{array}$} & \multicolumn{2}{|c|}{$\begin{array}{l}\text { Firm-level } \\
\text { agreement }\end{array}$} & \multicolumn{2}{|c|}{$\begin{array}{l}\text { No } \\
\text { agreement }\end{array}$} & \multicolumn{2}{|c|}{$\begin{array}{l}\text { Works } \\
\text { council }\end{array}$} \\
\hline & & I & II & 1 & II & I & II & I & II \\
\hline \multirow[t]{3}{*}{2000} & Germany & 48.6 & 55.1 & 3.1 & 8.3 & 48.2 & 36.6 & 11.5 & 41.7 \\
\hline & West & 54.0 & 59.3 & 2.6 & 8.0 & 43.3 & 32.7 & 12.1 & 44.3 \\
\hline & East & 28.7 & 37.8 & 5.0 & 9.7 & 66.3 & 52.5 & 9.3 & 31.2 \\
\hline \multirow[t]{3}{*}{2001} & Germany & 46.3 & 56.3 & 2.3 & 6.8 & 51.5 & 36.9 & 11.0 & 40.3 \\
\hline & West & 50.9 & 60.6 & 1.8 & 6.1 & 47.3 & 33.3 & 11.3 & 42.0 \\
\hline & East & 28.6 & 37.9 & 3.9 & 9.9 & 67.5 & 52.2 & 9.6 & 32.9 \\
\hline \multirow[t]{3}{*}{2002} & Germany & 45.6 & 55.6 & 1.7 & 5.4 & 52.7 & 39.0 & 9.2 & 38.3 \\
\hline & West & 50.0 & 60.0 & 1.3 & 4.7 & 48.7 & 35.3 & 9.4 & 39.8 \\
\hline & East & 24.9 & 33.2 & 3.4 & 9.1 & 71.7 & 57.7 & 8.1 & 30.8 \\
\hline \multirow[t]{3}{*}{2003} & Germany & 45.3 & 56.3 & 2.6 & 5.9 & 52.2 & 37.8 & 10.0 & 38.0 \\
\hline & West & 50.4 & 60.7 & 2.4 & 5.4 & 47.2 & 33.9 & 10.6 & 39.7 \\
\hline & East & 22.4 & 34.8 & 3.2 & 8.1 & 74.3 & 57.2 & 7.5 & 29.8 \\
\hline \multirow[t]{3}{*}{2004} & Germany & 40.8 & 50.8 & 2.3 & 7.2 & 56.8 & 42.1 & 9.6 & 36.6 \\
\hline & West & 44.8 & 53.5 & 2.4 & 7.4 & 52.9 & 39.1 & 10.2 & 37.8 \\
\hline & East & 22.5 & 37.5 & 2.1 & 6.0 & 75.4 & 56.4 & 6.9 & 31.1 \\
\hline \multirow[t]{3}{*}{2005} & Germany & 38.5 & 47.8 & 2.7 & 7.7 & 58.8 & 44.4 & 9.9 & 36.0 \\
\hline & West & 41.6 & 50.3 & 2.5 & 7.4 & 55.9 & 42.2 & 10.3 & 37.1 \\
\hline & East & 22.8 & 34.8 & 3.8 & 9.4 & 73.4 & 55.8 & 7.9 & 30.0 \\
\hline \multirow[t]{3}{*}{2006} & Germany & 35.2 & 43.8 & 2.6 & 7.1 & 62.3 & 49.1 & 9.1 & 33.3 \\
\hline & West & 37.1 & 45.3 & 2.5 & 6.7 & 60.4 & 48.0 & 9.4 & 34.3 \\
\hline & East & 25.6 & 36.1 & 3.0 & 9.0 & 71.4 & 54.8 & 7.4 & 28.2 \\
\hline \multirow[t]{3}{*}{2007} & Germany & 33.3 & 42.3 & 2.2 & 7.4 & 64.5 & 50.3 & 8.8 & 33.3 \\
\hline & West & 36.4 & 44.4 & 2.0 & 7.0 & 61.7 & 48.5 & 9.3 & 34.8 \\
\hline & East & 18.9 & 30.5 & 3.3 & 9.4 & 77.8 & 60.0 & 6.7 & 25.6 \\
\hline \multirow[t]{3}{*}{2008} & Germany & 30.6 & 42.0 & 2.1 & 6.1 & 67.3 & 51.9 & 7.9 & 30.2 \\
\hline & West & 32.8 & 44.2 & 1.9 & 5.0 & 65.2 & 50.8 & 8.2 & 31.0 \\
\hline & East & 20.4 & 31.5 & 2.8 & 11.3 & 76.8 & 57.2 & 6.3 & 26.2 \\
\hline \multirow[t]{3}{*}{2009} & Germany & 31.9 & 42.2 & 2.8 & 6.1 & 65.3 & 51.6 & 7.3 & 28.6 \\
\hline & West & 35.1 & 46.0 & 2.6 & 4.4 & 62.3 & 49.6 & 7.5 & 29.0 \\
\hline & East & 17.9 & 25.4 & 3.7 & 13.8 & 78.5 & 60.7 & 6.3 & 27.1 \\
\hline \multirow[t]{3}{*}{ Trend } & Germany & -*** & -*** & n.s. & n.s. & $+* * *$ & $+* * *$ & $-* * *$ & _*** \\
\hline & West & -**** & _*** & n.s. & n.s. & $+* * *$ & $+* * *$ & - **** & _*** \\
\hline & East & $-* * *$ & _*** & n.s. & n.s. & $+* * *$ & $+* *$ & $-* * *$ & _*** \\
\hline
\end{tabular}

Notes: I denotes the proportion of establishments and II the proportion of employees. $* * *, * *$, and $*$ denote statistical significance at the $.01, .05$, and .10 levels, respectively. 